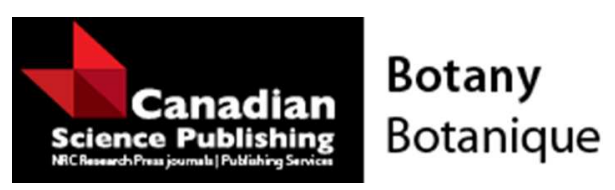

\title{
Revision of Icacinaceae from the Early Eocene London Clay flora based on X-ray micro-CT
}

\begin{tabular}{|r|l|}
\hline Journal: & Botany \\
\hline Manuscript ID & cjb-2016-0063.R1 \\
\hline Manuscript Type: & Article \\
\hline Date Submitted by the Author: & 06-May-2016 \\
\hline Complete List of Authors: & $\begin{array}{l}\text { Stull, Gregory; University of Florida, Florida Museum of Natural History } \\
\text { Adams, Neil; Royal Holloway University of London, Departments of Earth } \\
\text { Sciences and Geography } \\
\text { Manchester, Steven; University of Florida } \\
\text { Sykes, Dan; University of Manchester, School of Materials } \\
\text { Collinson, Margaret; Royal Holloway University of London, Department of } \\
\text { Earth Sciences }\end{array}$ \\
\hline Keyword: & endocarps, Eocene, Icacinaceae, Iodes, London Clay \\
\hline & \multicolumn{2}{|c|}{} \\
\hline
\end{tabular}

\section{SCHOLARONE ${ }^{\text {'H }}$}

Manuscripts 


\section{Revision of Icacinaceae from the Early Eocene London Clay flora based on X-ray micro- CT}

Gregory W. Stull, Neil F. Adams, Steven R. Manchester, Dan Sykes, and Margaret E. Collinson

G.W. Stull. Department of Biology and Florida Museum of Natural History, University of Florida, Gainesville, FL 32611, USA (email: gwstull@gmail.com).

N.F. Adams. Departments of Earth Sciences and Geography, Royal Holloway University of London, Egham, Surrey, TW20 0EX, UK (email: Neil.Adams.2012@live.rhul.ac.uk).

S.R. Manchester. Department of Biology and Florida Museum of Natural History, University of Florida, Gainesville, FL 32611, USA (email: steven@flmnh.ufl.edu).

D. Sykes. Imaging and Analysis Centre, Natural History Museum, London, SW7 5BD, UK. Current affiliation: School of Materials, University of Manchester, Oxford Road, Manchester, M13 9PL, UK (email: dan.sykes@postgrad.manchester.ac.uk)

M.E. Collinson. Department of Earth Sciences, Royal Holloway University of London, Egham, Surrey, TW20 0EX, UK; Department of Earth Sciences, Natural History Museum, Cromwell Road, London, SW7 5BD, UK (email: M.Collinson@es.rhul.ac.uk).

Corresponding author: G.W. Stull (email: gwstull@gmail.com; telephone: 1-614-406-2119; fax: N/A; address: Dickinson Hall (FLMNH), 1659 Museum Road, PO Box 117800, University of Florida, Gainesville, Florida 32611-7800). 


\begin{abstract}
The Early Eocene (Ypresian) London Clay Formation contains one of the most important fruit and seed assemblages from the Paleogene, including a large diversity of taxa ( $>350 \mathrm{spp}$.) preserved as pyrite permineralizations retaining 3D structure as well as anatomical detail. Despite the importance of the flora for understanding angiosperm biogeographic and evolutionary history, the majority of the fossil material has not been revisited since the original taxonomic treatments by E.M. Reid and M.E.J. Chandler. Given subsequent advances in our understanding of angiosperm phylogeny and fruit morphology, coupled with technological advances in imaging/visualizing fossil material, many of the taxa represented in the flora deserve further study. Here we present a revision of the pantropical family Icacinaceae using $\mu \mathrm{CT}$ images of 21 species from the flora. Based on the results, four new combinations are made, a new fossilgenus is established for a distinctive species with affinities to the Phytocreneae, and emended diagnoses are provided for eight taxa. Of the seven genera recognized from the flora, only one, Iodes Blume, is extant. This study offers important insights on the biogeographic and evolutionary history of Icacinaceae, which is one of the most abundant and diverse components of the flora from the London Clay Formation.
\end{abstract}

Key words: endocarps, Eocene, Icacinaceae, Iodes, London Clay, X-ray tomography 


\section{Introduction}

The London Clay Formation (Early Eocene, Ypresian: 56.0-47.8 Ma [Cohen et al. 2013]) of southeast England contains one of the most important fruit and seed assemblages from the Paleogene, including more than 350 described species (Collinson and Cleal 2001a). The flora is exceptional not only for its diversity, which is unparalleled by other well-studied Paleogene fossil floras (e.g., Manchester 1994; Collinson et al. 2012), but also its superb preservation. The fossil fruits and seeds are preserved predominantly as pyrite permineralizations and retain cellular detail as well as uncompressed, three-dimensional morphology (Reid and Chandler 1933; Chandler 1961), thereby offering excellent taxonomic resolution. Given its diversity and quality of preservation, the flora offers unique insight into the vegetation present in Europe during the long- and short-term hyperthermals of the early Eocene (Zachos et al. 2001, 2008), when increased global temperatures permitted the poleward expansion of thermophilic taxa.

Numerous clades now largely confined to tropical latitudes - e.g., Annonaceae, Arecaceae, Burseraceae, Icacinaceae, and Menispermaceae - are well documented in the flora (Reid and Chandler 1933; Chandler 1961). The London Clay fossils, in combination with records from other Eocene fruit and seed floras from Europe (e.g., Messel: Collinson et al. 2012) and North America (e.g., the Clarno Nut Beds: Scott 1954; Manchester 1994), provide important data on historical distributions of tropical plants. London Clay fossils also constitute the oldest reliable calibration points for many clades (e.g., Weeks et al. 2014). The flora has therefore greatly informed studies of angiosperm biogeographic and evolutionary history.

The London Clay flora was extensively monographed by Reid and Chandler (1933), who described nearly 300 species primarily from Sheppey, one of four major London Clay sites. Subsequent works (e.g., Chandler 1961, 1964, 1978) expanded on this original monograph, 
describing new species from the original sites and from additional sites of the London Clay Formation (e.g., Herne Bay and Bognor Regis). In her field guide to the flora, Collinson (1983) provided information on the relative stratigraphic positions within the London Clay Formation of the various sites from which the flora has been collected. Herne Bay (division A2) is one of the oldest sites (ca. 55-54.6 Ma) while Sheppey (divisions D and E) is one of the youngest (ca. 53.5-51.5 Ma) (Collinson 1983; Collinson and Cleal 2001a,b).

More recent studies (e.g., Mai 1980; Manchester et al. 2007, 2010; Manchester 2011) have clarified the systematic affinities of selected fossil taxa from the London Clay. However, the majority of the fossil material has not been revisited since the original treatments. Recent advances in our understanding of angiosperm phylogeny (e.g., Soltis et al. 2011) and fruit morphology of selected clades provide an excellent context for re-evaluating the systematics of numerous groups in the London Clay flora. Furthermore, technological advances in the imaging and visualization of fossil material (e.g., X-ray micro-computed tomography, $\mu \mathrm{CT}$ ) offer a means of non-destructively studying critically important specimens (e.g., holotypes) in high resolution (Smith et al. 2009). Collinson et al. (in review, this volume) demonstrate the utility and importance of this method for studying the London Clay material.

The flowering plant family Icacinaceae (Icacinales: Stevens 2001 onward; APG 2016) is an important component of the London Clay flora needing revision in light of new phylogenetic and morphological data. Icacinaceae are a pantropical clade of woody trees, shrubs, and climbers including 23 genera and $\sim 160$ species (Stull et al. 2015). One of the most diverse and abundant families in the London Clay flora, the Icacinaceae are represented by at least seven genera and 27 species, according to the original works of Reid and Chandler (1933) and Chandler (1961, 1964, 1978). The family, in the traditional sense (Engler 1893; Howard 1940; Sleumer 1942), 
was grossly polyphyletic (Soltis et al. 2000; Kårehed 2001), but recent phylogenetic work has greatly clarified the composition of the family and relationships within it (Byng et al. 2014; Stull et al. 2015). Furthermore, recent and ongoing studies of fruit morphology have highlighted characters useful for diagnosing clades within the family (e.g., Stull et al. 2011, 2012; Allen et al. 2015).

We present a systematic revision of Icacinaceae from the flora of the London Clay based on examinations of new $\mu \mathrm{CT}$ images of 21 (out of 27) of the previously recognized fossil species (mostly focused on their holotypes) in the context of new information on fruit morphology across all modern and fossil genera of the family. New combinations are established for three species from the flora, several of which have important nomenclatural consequences for other fossils of Icacinaceae from North America (Manchester 1994; Tiffney 1999; Allen et al. 2015) and Europe (Kvaček and Bůžek 1995); these are discussed herein. A new combination is also made for a species of Iodes from the Eocene of western North America with close affinities to a species from the London Clay (Iodes corniculata Reid et Chandler). We establish a new genus to accommodate a distinctive phytocrenoid taxon previously placed in the fossil genus Icacinicarya. Additionally, emended diagnoses are provided for eight taxa emphasizing characters found to be taxonomically useful in surveys of fossil and modern fruits across the family. Finally, the evolutionary and biogeographic implications of these fossils are discussed within the broader context of the family's phylogeny and fossil and modern distributions.

\section{Materials and methods}

In total, 27 species (as well as several informal species, e.g. "Icacinicarya sp. 11" and “Icacinicarya sp. 12"), based on more than 600 specimens, have been attributed to Icacinaceae 
from the various localities of the London Clay Formation (reviewed by Collinson and Cleal 2001a). Of these, 25 specimens housed in the Natural History Museum, London (NHMUK) were $\mu \mathrm{CT}$ scanned, representing 19 species (as well as the informal species noted above) primarily from the Sheppey site (Table 1). Where possible, holotypes were selected for scanning but, in some cases, the holotype was missing or too fragmented for study and so instead the best complete specimens originally assigned to the taxon by either Reid and Chandler (1933) or Chandler $(1961,1964,1978)$ were selected for analysis (Table 1). The species not scanned were excluded either because they were sufficiently documented in the original treatments for taxonomic assessment (i.e., Icacinicarya amygdaloidea Chandler, I. minima Reid and Chandler), the available specimens were too fragmented or degraded (e.g., endocarp missing) to yield useful additional information from $\mu \mathrm{CT}$ imaging (i.e., Icacinicarya bognorensis Reid and Chandler, $I$. emargina Chandler, I. jenkinsi Reid and Chandler, I. mucronata Chandler, I. ovoidea Reid and Chandler), or no specimens currently exist (i.e., Icacinicarya elegans (Bowerbank) Reid and Chandler). Appendix A1 provides specific reasons for excluding each of these eight species from $\mu \mathrm{CT}$ scanning.

The fossils were studied by $\mu \mathrm{CT}$ at the Imaging and Analysis Centre (NHMUK) using a Nikon Metrology HMX ST 225. The fossils are permanently stored in silicone oil to retard pyrite decay; to minimize potential damage from exposure during scanning, the specimens were placed in a pool of silicon oil in cavities cut into in small blocks of Plastazote ${ }^{\circledR}$ foam. Scanning was undertaken using a tungsten reflection target, at an accelerating voltage of $220 \mathrm{kV}$ and current of $200 \mu \mathrm{A}$ with an exposure time of $708 \mathrm{~ms}$ (giving a scan time of 38 minutes). A copper filter (1.5, 2.0 , or $2.5 \mathrm{~mm}$ thickness) was used and 3,142 projections were taken over a 360 rotation. The voxel sizes of the resulting datasets varied from 8 to $15 \mu \mathrm{m}$. Three-dimensional volumes were 
reconstructed using CT Pro (Nikon Metrology, Tring, UK) and TIFF stacks exported using VG Studio Max (Volume Graphics GmbH, Heidelberg, Germany). Datasets were visualized, and images and videos were captured, using Avizo 8.1 (FEI Visualization Science Group, Bordeaux, France). Images were adjusted uniformly for contrast and brightness using Adobe ${ }^{\circledR}$ Photoshop ${ }^{\circledR}$ CS2 or CS6. Videos of digital $\mu \mathrm{CT}$ tomograms through all of the London Clay Icacinaceae fossils scanned are available from the Dryad Digital Repository (http://dx.doi.org/10.5061/dryad.706df). The scans are also archived at NHMUK.

The fossil taxa were compared with modern fruits of all extant genera of Icacinaceae to evaluate their systematic affinities. We examined modern fruits, with particular attention to endocarp surface and internal characters revealed by physical sections, using herbarium material borrowed from or observed at FLAS, K, KUN, L, MO, P, U, UC, US and WAG. The extant species examined are listed in Appendix A2. The London Clay fossils were also compared with fossil taxa from other Paleogene floras in Europe (e.g., Kvaček and Bůžek 1995; Collinson et al. 2012) and North America (e.g., Manchester 1994; Tiffney 1999; Pigg et al. 2008; Rankin et al. 2008; Stull et al. 2011, 2012; Allen et al. 2015) through original observations or reference to the literature.

The examination and description of the London Clay material focuses primarily on previously undocumented characters (e.g., certain internal structural features, such as the position of the vascular bundle) as revealed by $\mu \mathrm{CT}$ imaging, to complement the original observations of Reid and Chandler (1933). The systematic evaluations are therefore based on both new and original observations. In the case of emended diagnoses, provided for eight taxa, additions or alterations to the original diagnoses, when only minor, are in italics. 


\section{Results}

Fruits of Icacinaceae are drupes with distinctive endocarps that are woody, unilocular, lenticular to circular in transverse section, and contain a single seed (Reid and Chandler 1933; Howard 1942). Fruit characters synapomorphic for Icacinaceae, as currently circumscribed (Stull et al. 2015), are unclear, because some of the genera recently removed from the family have similar overall fruit morphology (e.g., Calatola Standl., Dendrobangia Rusby, Poraqueiba Aubl., now in Metteniusaceae H. Karst.: Stull et al., 2015). However, some of the major clades within the family in its strict sense can be diagnosed using fruit morphological characters (Table 2), such as the ornamentation pattern on the endocarp surface (e.g., the presence of pits, ridges, or rugosities); the presence and morphology of projections into the locule cavity; the position (either inside or outside the endocarp wall) of the primary vascular bundle, which is referred to as the funicle in older literature (e.g., Reid and Chandler 1933); the configuration of apical apertures; and the presence of papillae lining the inner endocarp wall (Reid and Chandler 1933; Manchester 1994; Kvaček and Bůžek 1995; Stull et al. 2012, 2015; Allen et al. 2015). The seeds also generally have a slight vertical indentation on one lateral face, bearing the raphe. We therefore emphasized these characters in the systematic treatment of fossil taxa outlined below.

In total, 24 species (including the informal "Icacinicarya sp. 12") from the flora of the London Clay Formation are confirmed as Icacinaceae (18 of these were scanned), while "Icacinicarya" foveolata is rejected as a member of the family. Another four (including the informal "Icacinicarya sp. 11) species attributed to the family can neither be accepted nor rejected due to poor preservation or the absence of distinct/diagnostic characters: "Icacinicarya" bognorensis, "Icacinicarya" mucronata, "Icacinicarya" rotundata, "Icacinicarya" sp. 11. Among the accepted species, several new combinations (established below) are necessary in 
light of information revealed by $\mu \mathrm{CT}$. These involve species belonging to, or incorrectly attributed to, the extant genus Iodes: Iodes bilinica (Ettingshausen) Stull, Adams, Manchester et Collinson, comb. nov. (previously placed in Natsiatum, as well as several other genera) and Icacinicarya davisii (Chandler) Stull, Adams, Manchester et Collinson, comb. nov. (previously included in Iodes). These new combinations have important nomenclatural consequences (discussed below), in particular for European fossils attributed to the fossil genus Palaeohosiea Kvaček et Bůžek. Our examinations of fossil and modern Iodes also made it clear that fossils recently named Biceratocarpum brownii (Allen et al. 2015) belong to this extant genus; we therefore establish Iodes brownii (Berry) Stull, Adams, Manchester et Collinson herein.

For eight species, emended diagnoses are provided (given the new information from $\mu \mathrm{CT})$. A new genus is described below to accommodate a species that was formerly included in Icacinicarya; this new genus has clear affinities with the Phytocreneae tribe but also differs from the other modern and fossil genera. Our treatment of Icacinicarya Reid et Chandler, originally established as a genus for Icacinaceae fossils of uncertain placement, is relatively limited, but we provide important discussion of how this generic concept applies to the fossil record of Icacinaceae as currently circumscribed (Stull et al. 2015).

\section{Systematics}

\section{Icacinaceae Miers}

Iodes Blume

Iodes bilinica (Ettingshausen) Stull, Adams, Manchester et Collinson, comb. nov.

Fig. 1.

Basionym: Amygdalus bilinica Ettingshausen 1869 (pp. 55, pro parte, pl. 53, fig. 22 [non fig. 23]) 
Synonyms: Natsiatum eocenicum Chandler 1925; Prunus bilinica (Ettingshausen) Mai 1963;

Hosiea eocenica (Chandler) Takhtajan 1966; Hosiea bilinica (Ettingshausen) Holý 1978;

Palaeohosiea bilinica (Ettingshausen) Kvaček and Bůžek 1995.

Emended specific diagnosis: Endocarp broadly oval in lateral view, only slightly inflated, boldly ornamented with a network of prominent acute ridges, including frequent freely ending ridgelets. Endocarp with prominent keel along one margin, bearing the primary vascular bundle embedded within the endocarp wall. Locule lining finely papillate. Endocarp 9-16 mm in length, $7-11 \mathrm{~mm}$ in width, and 5-6 $\mathrm{mm}$ in thickness.

Neotype: NM.G 364 (pl. 4, fig. 24 in Sieber 1880; pl. 1, fig. 15 in Kvaček and Bůžek 1995). [Original holotype of Natsiatum eocenicum (V42149, illustrated in Chandler 1925: p. 29, pl. 4, fig. 7a-d) decayed; neotype of N. eocenicum: V40614 (Chandler 1962, p. 96, pl. 13, fig. 13). For the basis of this revised lithostratigraphy and further details of the Hordle flora see Collinson and Cleal (2001b).].

Specimen scanned: V45055 (representative from London Clay; Fig. 1), figured by Chandler (1964, pl. 4, fig. 1) and by Collinson (1983, text-fig. 63). The older collections of this taxon from the London Clay are noted in NHMUK as "not found 26-9-75."

Description: Endocarp bisymmetrical (Fig. 1C, F, H-I), unilocular, broadly oval in lateral view (Fig. 1A, B), lenticular in cross section (Fig. 1H-I), with a distinctly keeled margin bearing the vascular bundle embedded within the endocarp wall (Fig. 1C, H, J). Endocarp apex slightly asymmetrical, with a pair of subapical channels/pores near the margin bearing the vascular bundle, with one channel on each lateral face (Fig. 1A); the subapical channels flank the stylar canal. Endocarp surface covered with a network of ridges, with areoles irregular in size and with more frequent freely ending ridgelets (Fig. 1A, B). Depressions/concavities of endocarp surface 
(=the areoles, or areas encircled by ridges) represented by convexities on the inner endocarp surface (Fig. 1D, E). Inner endocarp surface finely papillate (Fig. 1E). Endocarp 9-16 mm in length, 7-11 in width, and 5-6 mm in thickness.

Remarks: The London Clay specimens of the species were assigned by Reid and Chandler (1933) to a species that Chandler (1925) had described earlier based on carbonized endocarps from the Late Eocene of Hordle. Although originally placed in the extant genus Natsiatum (Chandler 1925, 1962), and more recently in the fossil genus Palaeohosiea (Kvaček and Bůžek 1995), this species possesses the key diagnostic feature of Iodes, i.e., the position of the vascular bundle embedded within (rather than outside) the endocarp wall. Like most other genera of Icacinaceae, the vascular bundle of Natsiatum runs within a conspicuous canal on the outside of the endocarp wall. The other features shown by this fossil species - the network of ridges on the endocarp surface, the symmetry and endocarp shape, the presence of subapical channels/pores, and the papillate locule lining (Chandler 1962; Kvaček and Bůžek 1995) - are also consistent with extant Iodes. This species is therefore transferred from Natsiatum to Iodes, as Iodes bilinica (Ettingshausen) Stull, Adams, Manchester et Collinson, comb. nov.. Compared to other species of Iodes from the London Clay, Iodes bilinica is distinctive in having prominent ridges with numerous freely ending ridgelets. I. corniculata, by comparison, essentially lacks freely ending ridgelets. Furthermore, the subapical pores of I. corniculata are borne within prominent horn-like structures, which are absent from I. bilinica and other Icacinaceae species with subapical pores. Iodes bilinica was perhaps the most abundant and widely distributed taxon of Icacinaceae in the European Paleogene, with occurrences in the London Clay (both Bognor and Sheppey), as well as numerous other localities in England (see Chandler 1964, p. 27) and the Czech Republic (Kvaček and Bůžek 1995). Chandler's (1925) attribution to Natsiatum was based on comparisons 
with extant Natsiatum sinense Oliv. However, because $N$. sinense is a synonym of the accepted name Hosiea sinensis (Oliv.) Hemsl. \& E.H. Wilson, Takhtajan (1966) established the combination Hosiea eocenica (Chandler) Takhtajan for this species. Subsequently, based on comparisons of the British material with endocarps from the Paleogene of Germany and the Czech Republic, Mai and Walther (1978) and Mai (1987) split Hosiea eocenica into two species. One species, Hosiea marchiaca Mai, encompassed smaller endocarps spanning from the Paleocene to early Eocene in Germany and the United Kingdom. The other species, Hosiea bilinica (Ettingshausen) Holý, encompassed larger endocarps, including London Clay fossils as well as endocarps originally attributed by Ettingshausen (1869) to Amygdalus (as A. bilinica, the basionym, hence Hosiea bilinica). Subsequently, Kvaček and Bůžek (1995) established the fossil genus Palaeohosiea to accommodate a new species, $P$. suleticensis, as well as the two "Hosiea" species mentioned above, under the new combinations $P$. bilinica (including the fossils previously named Natsiatum eocenicum) and P. marchiaca. However, as noted by Allen et al. (2015), the diagnosis of Palaeohosiea contains no significant distinctions from the extant genus Iodes and, therefore, the various fossils included in the 'Palaeohosiea complex' likely represent this genus.

The emended diagnosis presented here applies more specifically to fossils examined from the London Clay and related sites from the Eocene of England, but it is also compatible with observations of the type material from the Czech Republic. Fossils from the middle Eocene of Messel, Germany, also attributed to this species, as Palaeohosiea bilinica (Collinson et al. 2012) resemble the London Clay representative in endocarp size and sculpture. However, from those specimens, the position of the primary vascular bundle (inside or outside the endocarp wall) and 
the presence or absence of papillae on the locule lining could not be verified. The generic position of the Messel material therefore needs to be revisited.

Iodes corniculata Reid et Chandler emend. Stull, Adams, Manchester et Collinson

Fig. 2

Emended specific diagnosis: Endocarp broadly oval, or ovate, in lateral view, lenticular in transverse section, ornamented with fifteen to twenty shallow concave areas separated by ridges, with a tendency to be arranged in four longitudinal rows. Marginal vascular bundle embedded within the endocarp wall. Style flanked by a horn-like projection on each lateral face; locule lining papillate. Length, 8 to $9 \mathrm{~mm}$; breadth, 5.5 to $7 \mathrm{~mm}$, thickness, $4 \mathrm{~mm}$. Seed: testa cells, $0.025 \mathrm{~mm}$ in diameter.

Holotype: V22579 (Fig. 2A-J), originally figured by Reid and Chandler (1933; pl. 14, figs. 3436).

Specimen scanned: V22579 (holotype).

Description: Endocarp bisymmetrical (Fig. 2F, J), oval to ovate (Fig. 2C, K, L), lenticular in transverse section (Fig. 2H-I), with a rounded base and an asymmetrical apex, as seen in lateral views (Fig. 2C, D, K, L) Endocarp surface covered with ridges, forming closed, slightly depressed areoles with only a few freely ending ridgelets (Fig. 2C). Inner endocarp surface (locule lining) reflects the ridges and depressions on the external endocarp surface (as shown by the locule cast in Fig. 2D-F). Inner endocarp surface papillate (demonstrated by minute punctations covering the locule cast in Fig. 2D-F). Reid and Chandler (1933) observed these to be three to four in $0.25 \mathrm{~mm}^{2}$. Primary vascular bundle travels from the base of endocarp along one margin, within the endocarp wall (Fig. 2H-I), to the asymmetrical apex (Fig. 2D), where it 
enters the locule cavity. Apical bulge denotes the entry of the vascular bundle into the locule (Fig. 2D). A pair of subapical horns, one on each endocarp face, connects to the vascular bundle at the point of entry into the locule (Fig. 2A-B, E, J). Subapical horns each bearing a canal (Fig. 2G). Style apical, stylar canal entering the endocarp at the confluence of the vascular bundle and subapical horns (Fig 2D-F). Endocarp 8-9 $\mathrm{mm}$ in length, 5.5-7 $\mathrm{mm}$ in width, and ca. $4 \mathrm{~mm}$ in thickness.

Remarks: This species possesses numerous features consistent with extant species of Iodes, including a ridged endocarp surface, a papillate locule lining, and the primary vascular bundle positioned within the endocarp wall (in other genera of Icacinaceae, it runs outside the endocarp wall, through the mesocarp), as confirmed by $\mu \mathrm{CT}$ (Fig. 2). Additionally, several Asian species of Iodes (I. cirrhosa Turcz. and I. ovalis Blume) possess subapical, horn-like protrusions similar to those of I. corniculata. No African or Malagasy species of Iodes that we observed possess this feature, suggesting that I. corniculata might be more closely related to at least certain Asian species of the genus.

The horn-like apical structures were also recently observed in a morphologically similar fossil taxon, Biceratocarpum brownii (Berry) Stull, S.E. Allen et Manchester, from the Eocene of western North America (Allen et al. 2015). In erecting the new genus Biceratocarpum, the authors were unaware that several Asian species of Iodes possess subapical horns, and therefore established this fossil genus to accommodate fossils with this morphologically distinct feature. However, given that several Asian species of Iodes possess subapical horns, it is considered preferable to treat this species under the new combination Iodes brownii (Berry) Stull, Adams, Manchester et Collinson, which we establish below. 
Molecular data support that the "horned" species of Iodes (e.g., I. cirrhosa) do indeed form a clade with the other Iodes species sampled to date (Stull et al., 2015). I. corniculata and I. brownii are consistent in their size and overall morphology (embedded vascular bundle, papillate locule lining, endocarp areoles with few to no freely ending ridgelets), but $I$. corniculata has fewer areoles/concavities on each endocarp face, supporting its recognition as a separate species. Iodes corniculata is abundant at the Sheppey site of the London Clay Formation, and has been recognized at Herne Bay as well, but it has not been documented at other European Paleogene sites to date.

Iodes brownii (Berry) Stull, Adams, Manchester et Collinson, comb. nov. Basionym: Carpolithus browni Berry 1930 (pp. 78-79, pl. 14, fig. 1).

Synonym: Biceratocarpum brownii (Berry) Stull, S.E. Allen et Manchester 2015 (pp. 727-731, figs $3,4 \mathrm{~A}, 5)$.

Diagnosis (emended by Stull, S.E. Allen et Manchester): Endocarp ellipsoidal in lateral view, lenticular in cross section, 7.5-9.5 mm long, 5-7.5 mm wide, unilocular, bivalved. Outer surface covered with a reticulum of ridges delimiting polygonal areoles (ca. 20-25 total) with few or no freely ending ridgelets. Course of the marginal vascular bundle embedded in the endocarp wall. Endocarp possessing a symmetrical pair of horn-like protrusions, positioned eccentrically and subapically on the outer endocarp faces, each apparently accommodating a central channel. Inner endocarp surface showing shallow mounds corresponding to areoles/depressions of outer endocarp reticulum. Inner endocarp surface densely covered with regularly spaced, minute papillate; papillae average $0.03 \mathrm{~mm}$ apart. Endocarp wall $0.3-0.4 \mathrm{~mm}$ thick.

Holotype: USNM 316745 (pl. 14, fig. 1 in Berry 1930; figs. 3D-E, 4A in Allen et al. 2015). 
Occurrence: Eocene of Aycross Formation (Tipperary and Kisinger Lakes floras), and Bridger Formation (Blue Rim,Wyoming), Parachute Creek Member of Green River Formation, Utah, and Clarno Nut Beds, Oregon, USA.

Remarks: The genus Biceratocarpum Stull, S.E. Allen et Manchester was established for this species in recognition of its distinctive subapical "horn-like" structures (Allen et al. 2015), which seemed to distinguish it from extant Iodes. However, in establishing the genus, the authors were unaware that several modern species of Iodes have similar subapical horn-like structures. We therefore transfer this species to Iodes, as it shows no major features distinguishing it from this extant genus.

\section{Iodes eocenica Reid et Chandler}

Fig. 3.

Original diagnosis: Endocarp circular or oval in lateral view, lenticular in transverse section, surface with a coarse network of broad, low, rounded ridges, enclosing slightly hollowed spaces; locule lining papillate. Length, 13.5 to $15 \mathrm{~mm}$; breadth, $12 \mathrm{~mm}$; thickness, 5 to $6 \mathrm{~mm}$. Seed with testa cells averaging $0.031 \mathrm{~mm}$ in diameter.

Holotype: V22615, originally figured by Reid and Chandler (1933; pl. 15, figs. 12-14).

Specimen scanned: V22617 (best remaining specimen; Fig. 3A-G).

Description: Endocarp bisymmetrical (Fig. 3C-D), unilocular, oval in lateral view (Fig. 3A-B), flattened and lenticular in transverse section (Fig. 3G). Endocarp surface ornamented with a network of broad, rounded ridges, delimiting small areoles/concavities (Fig. 3A-B). Primary vascular bundle runs within the endocarp wall from base to apex, where it sharply turns to enter the locule, forming the apical placenta (observed by Reid and Chandler 1933; not confirmed 
here). Endocarp wall relatively thick, the other layers parenchymatous, composed of interlocking digitate cells. Locule lining (inner endocarp wall) finely papillate; spaces between papillae approximately equal to the diameter of the papillae. Endocarp 13.5 to $15 \mathrm{~mm}$ in length, $12 \mathrm{~mm}$ in breadth, 5 to $6 \mathrm{~mm}$ in thickness.

Remarks: This species was named by Reid and Chandler (1933) based on some specimens in a vial that Ettingshausen had labeled Amydalus eocenicum (the same species treated herein as Iodes bilinica), but which they found to be distinct from the type material of that species.

Although originally identified as Amygdalus by Ettingshausen (1879), Reid and Chandler (1933) outlined multiple reasons why it belongs in Icacinaceae rather than the Prunoideae (=Amygdaloideae) of Rosaceae: for example, the primary vascular bundle does not gradually enter the locule, as is the case in Prunoideae, but instead sharply turns to enter the locule near the apex; furthermore the species has a papillate locule lining, in contrast with members of Prunoideae. The other features observed by Reid and Chandler (1933), e.g., the position of the vascular bundle within the endocarp wall and the external ornamentation of a network of ridges, are consistent with the extant genus Iodes. However, due to abrasion of the endocarp wall of the specimen we scanned, we were unable to confirm the position of the primary vascular bundle. In the absence of new data on the vascular bundle position, we defer to the original observations and treatment of Reid and Chandler (1933) and retain this species in Iodes.

\section{Iodes multireticulata Reid et Chandler}

Fig. 4.

Original diagnosis: Endocarp oval or ovate in lateral view, slightly narrowed at the apex, lenticular in transverse section, surface with thirty to fifty concave areas irregularly arranged; 
locule lining papillate. Length, 8 to $12.5 \mathrm{~mm}$; breadth, 4 to $7.5 \mathrm{~mm}$; thickness $3.4 \mathrm{~mm}$. See with testa cells, $0.025 \mathrm{~mm}$ in diameter.

Holotype: V22589 (Fig. 4A-G, I-K), originally figured by Reid and Chandler (1933; pl. 15, fig. 1). Specimens scanned: V22589 (holotype), V22595 (Fig. 4H, L, M), V22591 (Fig. 4N-Q), and V22599.

Description: Endocarp bisymmetrical (Fig. 4G), unilocular, bivalved, ovate to oval in lateral view (Fig. 4A, D, K), lenticular in transverse section (Fig. 4F-M), with a rounded based and an asymmetrical, slightly pointed apex (Fig. 4A, D, K). Endocarp surface covered with ridges forming thirty to fifty enclosed areoles/concavities, somewhat irregularly arranged, with occasional freely-ending ridgelets penetrating the enclosed areoles (Fig. 4A, D). Primary vascular bundle enters the endocarp at the base and travels, through the wall, toward the apex, where it enters the locule becoming the apical placenta - as observed by Reid and Chandler (1933); unable to confirm through $\mu \mathrm{CT}$ imaging. Endocarp wall thick, composed of digitate cells, $0.016 \mathrm{~mm}$ in diameter. Locule lining papillate (Reid and Chandler 1933); the papillae (one per cell) extending from interlocking digitate cells composing the inner endocarp wall.

Compared to I. corniculata, the papillae are larger and spaced further apart. Endocarp 8-12.5 $\mathrm{mm}$ in length, 4-7.5 $\mathrm{mm}$ in breadth, ca. $3.4 \mathrm{~mm}$ in thickness.

Remarks: This species is represented by over 100 specimens, primarily from Sheppey but also from Herne Bay (Reid and Chandler 1933). As originally described, this species possesses all the key diagnostic features of Iodes. However, our $\mu \mathrm{CT}$ imaging was unable to confirm the position of the primary vascular bundle, a key diagnostic feature of Iodes. The specimens scanned (which include the holotype and several specimens noted in the original publications to have the 
endocarp preserved) were too abraded or degraded from pyrite decay to observe this character with confidence. One of us (MEC) examined all specimens in the NHMUK collections in 2015. Much of the endocarp wall thickness has been lost in most specimens, surviving only as a thin black film adhering to the pyrite locule cast. This species is therefore tentatively retained in Iodes, on the basis of Reid and Chandler's (1933) original observations. We recommend $\mu \mathrm{CT}$ imaging of freshly collected specimens to verify the position of the vascular bundle in this species.

This species has also been recognized from Eocene of Oregon (Clarno Nut Beds: Manchester 1994) and Virginia (Nanjemoy Formation: Tiffney 1999). One of the specimens attributed to I. multireticulata from the Clarno Nut Beds (UF 6458; pl. 17, figs. 3, 4 in Manchester 1994), however, possesses subapical horns and a surface ornamentation pattern similar to I. brownii. Additional study of the Clarno material is therefore necessary to determine whether some or all of the specimens attributed to I. multireticulata actually belong to another species, e.g., I. brownii. Tiffney (1999) recognized I. multireticulata from the Eocene of Virginia based on two broken endocarps. The characters observed in this species match those of Iodes, but the scarcity and fragile condition of those pyritized specimens makes comparisons with individual species of Iodes difficult.

Faboidea Bowerbank emend. Stull, Adams, Manchester et Collinson

Because only a single species of Faboidea is known at present, the diagnosis of the genus (Faboidea) and species (F. crassicutis) are the same. The combined generic and specific diagnosis, which we emend, is provided below.

Type species: Faboidea crassicutis Bowerbank. 
Faboidea crassicutis Bowerbank emend. Stull, Adams, Manchester et Collinson

Fig. 5.

Emended diagnosis: Endocarp bisymmetrical, unilocular, bivalved, squat in shape (broader than tall), transversely oval, with a slightly asymmetrical apex. Endocarp surface irregularly corrugated. Primary vascular bundle embedded within the endocarp wall. Locule lining papillate. Endocarp length 15-19 mm, width 19-20 mm, thickness 7-14.5 mm; endocarp wall notably thick $(1.5-3.5 \mathrm{~mm})$. Seed anatropous, pendulous, with a distinctive groove running down one lateral face, marking the course of the raphe.

Holotype: V22660 (Fig. 5), originally figured by Bowerbank (1840; pl. 15, figs. 6-8) and by Reid and Chandler (1933; pl. 16, fig. 3).

Specimen scanned: V22660 (holotype).

Description: Endocarp bisymmetrical (Fig. 5A-D), unilocular, bivalved, vertically flattened (Fig. 5B, C), with a greater width (ca. 19-25 mm) than length (15-19 mm). Endocarp oval in transverse section, ca. 7-14.5 mm in thickness. Endocarp surface irregularly corrugated (Fig. 5A-D). Endocarp apex asymmetrical, with a slight bulge marking the entrance of the primary vascular bundle into the locule (no longer observable from holotype due to damage to the apex; Reid and Chandler 1933). Primary vascular bundle runs from the base of the endocarp to the apex within the endocarp wall (Fig. 5H), which is notably thick (1.5-3.5 mm). Locule lining with a papillate surface (Reid and Chandler 1933). Seed broader than long, oval in transverse section, pendulous from the apex, anatropous, with the raphe running down a distinctive groove on one lateral face of the seed (pl. 16, fig. 7 in Reid and Chandler 1933). 
Remarks: The placement of Faboidea within Icacinaceae is supported by its bivalved structure, its symmetry, the trajectory of the primary vascular bundle, its seed morphology (e.g., the raphe runs down one lateral face), and its cellular details (described by Reid and Chandler 1933). Furthermore, several characters suggest affinities with the extant genus Iodes, including the embedded vascular bundle and the papillate locule lining. Several extant species of Iodes (e.g., I. cirrhosa) also have distinct grooves on one lateral seed face, bearing the raphe. However, unlike Iodes, Faboidea is distinct in having a corrugate (rather than distinctly ridged) endocarp surface and a squat (wider than long) endocarp shape. The endocarp wall in F. crassicutis (up to $3.5 \mathrm{~mm}$ ) is also much thicker than most species of Iodes (generally $0.25-1 \mathrm{~mm}$ ). For these reasons, we retain this species within the fossil genus Faboidea, although it is probably closely related to extant Iodes. Reid and Chandler (1933) also noted affinities with the extant genus Iodes but concluded that the shape and surface of the fossil endocarps precluded placement in this genus.

Faboidea crassicutis is an abundant component of the London Clay flora, represented by over 120 specimens from Herne Bay and Sheppey, which are variable in shape, size, and appearance, perhaps due to a combination of natural variation and vagaries of preservation (Reid and Chandler 1933). Reid and Chandler (1933) note that, because most endocarps of this species have suffered abrasion, its surface sculpture is somewhat uncertain. Despite its abundance and age range in the London Clay Formation, F. crassicutis has not, to our knowledge, been documented at any other fruit and seed localities from the Paleogene of Europe. The genus Comicilacium Manchester from the Clarno Formation of Oregon (Manchester 1994), is similar in shape, size, bivalved construction and papillate locule lining, but has a prominent lip-like apical bulge on the endocarp, but it remains uncertain whether the main vascular bundle was within, or external to, the endocarp wall. 
Sphaeriodes Reid and Chandler emend. Stull, Adams, Manchester et Collinson

Because only a single species of Sphaeriodes is known at present, the diagnosis of the genus (Sphaeriodes) and species (S. ventricosa) are the same. The combined generic and specific diagnosis, which we emend, is provided below.

Type species: Sphaeriodes ventricosa (Bowerbank) Reid et Chandler.

\section{Sphaeriodes ventricosa (Bowerbank) Reid et Chandler}

Fig. 6.

Emended diagnosis: Endocarp globular, coarsely nodular externally, style flanked by a pair of lateral knobs; locule lining minutely papillate. Primary vascular bundle embedded within the endocarp wall from base to apex. Endocarp length 10-16 mm; width 10-15 mm; thickness 10$14 \mathrm{~mm}$. Endocarp wall thick, composed of large sclereids with sinuous, irregular walls. Seed with cells of the testa but slightly inflated, $0.015-0.016 \mathrm{~mm}$ in diameter.

Holotype: V22619, originally figured by Bowerbank (1840; pl. 16, figs. 4-6) and by Reid and Chandler (1933; pl. 15, figs. 18, 19).

Specimen scanned: V22620 (most complete specimen; Fig. 6), figured by Reid and Chandler (1933; pl. 15, fig. 20).

Description: Endocarp bisymmetrical (Fig. 6A, D, H), unilocular, globular, with an irregularly rugose external surface (Fig. 6A, B). Primary vascular bundle runs from base to apex within the endocarp wall (Fig. 6L). Apex of endocarp bearing a pair of knob-like structures, flanking the primary vascular bundle and style, composed of fibrous strands arising from the vascular bundle (http://dx.doi.org/10.5061/dryad.706df). Endocarp wall thick, woody, composed of sclereids 
with irregular, sinuous walls. Locule lining finely papillate; papillae ca. $16 \mu \mathrm{m}$ in diameter. Endocarp 10-16 $\mathrm{mm}$ in length, $10-15 \mathrm{~mm}$ in width, and 10-14 $\mathrm{mm}$ in thickness. Remarks: This species, like Faboidea crassicutis, shares important similarities with Iodes (including an embedded vascular bundle and a papillate locule lining) but also notable differences in shape and surface morphology. S. ventricosa is notably globose; with the exception of several species (e.g., Iodes perrieri Sleumer), Iodes tends to have endocarps that are lenticular in transverse section. The endocarp surface of $S$. ventricosa, in contrast to the ridged endocarps of Iodes, is irregularly rugose, resembling species in several other icacinaceous genera (e.g., Cassinopsis Sond., Mappia Jacq.). This species therefore appears to display a combination of characters distinct from any particular modern genus and is retained in the fossil genus Sphaeriodes, which highlights its similarity, in several respects, to Iodes.

\section{Palaeophytocrene Reid et Chandler emend. Stull, Adams, Manchester et Collinson}

Emended generic diagnosis: Endocarp oval in lateral view, compressed or slightly inflated, obscurely pitted externally, the closer inner ends of the pits forming conical to parallel-sided protuberances projecting into the locule. Locule lining often finely papillate.

Type species: Palaeophytocrene foveolata Reid et Chandler.

Remarks: Reid and Chandler established the genus Palaeophytocrene for fossils of Icacinaceae clearly belonging to Phytocreneae but with important distinctions from the extant genera. For example, the shape of the endocarp and the distribution of surface pits in Palaeophytocrene matches that of Phytocrene Wall.; however, Phytocrene lacks broad tubercles into the locule. The tubercles of Miquelia Meisn. are similar to those of Palaeophytocrene (in being broad and somewhat conical), but the endocarps surfaces of Miquelia are often ornamented with sharp 
ridges in addition to pits, unlike Palaeophytcrene. We note, however, that the endocarps of fossils attributed to Palaeophytocrene from London Clay are often abraded or absent, with only locule casts remaining, making it difficult to determine the presence or absence of ridges on the surface. The genera Pyrenacantha Wight and Stachyanthus Engler have much smaller, and more numerous, surface pits, corresponding to either narrow spinelike tubercles or small bump-like protuberances, rather than large, broad (often conical) tubercles. Reid and Chandler (1933) noted that papillae were absent from fruits of Palaeophytocrene. However, subsequent investigations revealed that Palaeophytocrene foveolata has a papillate locule lining (Rankin et al. 2008). Manchester (1994) had previously documented that Palaeophytocrene fossils from the Eocene Clarno Formation have a finely papillate locule lining. These papillae appear much smaller than those typically seen in Iodes, perhaps explaining why Reid and Chandler overlooked them. A subsequent study of Palaeophytocrene from British Columbia, documenting several new species of the genus, also noted the presence of papillae on the fossils (Rankin et al. 2008). The genus is also known from compression fossils in the middle Eocene of Messel, Germany (Collinson et al. 2012), although the presence or absence of papillae on these fossils is unknown.

Palaeophytocrene foveolata Reid et Chandler emend. Stull, Adams, Manchester et Collinson Fig. 7.

Emended specific diagnosis: Endocarp with surface pits about twelve in length of the nut and eight in the width. Length, 15 to $27 \mathrm{~mm}$; breadth 14 to $17 \mathrm{~mm}$; thickness, 5.5 to $13 \mathrm{~mm}$. Locule lining papillate. Seed with testa cells inflated 0.05 to $0.15 \mathrm{~mm}$ in diameter.

Holotype: V22633, originally figured by Reid and Chandler (1933; pl. 15, figs. 24, 25). 
Specimen scanned: V22635 (best complete specimen; Fig. 7), figured by Reid and Chandler (1933; pl. 15, figs. 27, 28).

Description: Endocarp bisymmetrical (Fig. 7D, E, G), unilocular, oval in lateral view (Fig. 7A, C), lenticular in transverse section (Fig. 7J). Endocarp surface ornamented with broad pits corresponding to large, vertical-sided protuberances projecting into the locule (inferred from pits in locule cast; Fig. 7A, C, I-J). Pits smaller and more numerous than those of P. ambigua, arranged in irregular longitudinal rows (Fig. 7A, C). Endocarp wall (rarely preserved) composed of interlocking cells. Locule lining composed of polygonal cells $(0.025 \mathrm{~mm})$, each bearing a small papilla, thus collectively forming a papillate lining (fig. 5D in Rankin et al. 2008). The features of the vascular bundle(s) supplying the seed unknown, due to the abrasion of the endocarp; most specimens are locule casts with, at most, only patches of endocarp wall. Locule casts (with adhering endocarp) $15-27 \mathrm{~mm}$ in length, $14-17 \mathrm{~mm}$ in width, 5.5-13 $\mathrm{mm}$ in thickness.

Remarks: This species, the type of Palaeophytocrene, is represented by ca. 25 specimens (mostly pyrite locule casts) from the London Clay. Reid and Chandler (1933) interpreted a slight attenuation at one end of the endocarp as the style, and therefore oriented that end as the apex (pl. 15, figs. 24-28 in Reid and Chandler 1933). Our observations of Phytocreneae endocarps, however, suggest that attenuated portion represents the base; this interpretation makes the endocarp ovate (rather than obovate) in shape, consistent with the majority of Phytocreneae fruits observed.

The features of this species match closely with members of the Phytocreneae tribe, which have woody, pitted endocarps often with tuberculate protrusions into the locule. Compared to modern genera of Phytocreneae, $P$. foveolata most closely matches fruits of Phytocrene in terms 
of surface pit size and arrangement; fruits of Pyrenacantha and Stachyanthus generally have much denser and smaller pits, while Miquelia fruits tend to have ridges encircling the surface pits. We note, however, that since most specimens of $P$. foveolata have little remaining endocarp, due to abrasion, it is difficult to determine if this species had ridge-like ornamentation on the endocarp surface in addition to the pits. Palaeophytocrene foveolata, unlike Phytocrene, has broad tubercles extending deeply into the locule. These are somewhat similar to those of Miquelia, but the latter genus tends to have sloped (rather than parallel-sided) tubercles.

Palaeophytocrene foveolata also has a papillate locule lining, consistent with Miquelia and in contrast with Phytocrene, in which papillae are absent. Collectively this species appears to exhibit a combination of features found in Phytocrene and especially Miquelia, but does not perfectly match either. Accordingly, this species is retained in Palaeophytocrene, acknowledging its affinities with the Phytocreneae tribe while also recognizing it as distinct from extant genera.

Palaeophytocrene ambigua Reid et Chandler emend. Stull, Adams, Manchester et Collinson

Fig. 8.

Emended specific diagnosis: Endocarp surface covered with pits arranged in irregular longitudinal rows, approximately eight to nine in length and four to five in width. Surface pits correspond to relatively large, funnel-shaped tubercles projecting into the locule. Length (of locule cast) $22 \mathrm{~mm}$; width (of locule cast) $12.5 \mathrm{~mm}$.

Holotype: V22646 (Fig. 8), originally figured by Reid and Chandler (1933; pl. 15, fig. 34). Specimen scanned: V22646 (holotype).

Description: Endocarp bisymmetrical (Fig. 8C, D), unilocular, lenticular in transverse section

(Fig. 8F, G). Endocarp surface covered with pits, corresponding to tuberculate intrusions into the 
locule (inferred from pits on locule casts; Fig. 8A, B). Ornamentation of endocarp (beyond the presence of pits) incompletely known given the material available (two locule casts with incomplete endocarp). However, remnant endocarp on one specimen indicates that the wall was relatively thick (e.g., Fig. 8B-D, G, H). Pits (and tubercles) are fewer and larger than those of $P$. foveolata, with ca. four to five pits spanning the width and 8 to 9 pits spanning the length of the endocarp (Fig. 8A, B); pits tend to be arranged in loose longitudinal rows. Tubercles (i.e., portion of endocarp extending into the locule) broader and more funnel shaped compared to those of $P$. foveolata (inferred from the shape of the depressions on the locule casts of both species); tubercle impressions are ca. $2 \mathrm{~mm}$ in diameter on the locule cast. Tubercles, although conical in overall shape, bearing parallel-sided canals that form the pits on the endocarp surface. Locule cast of endocarp $22 \mathrm{~mm}$ in length, $14.5 \mathrm{~mm}$ in width.

Remarks: Palaeophytocrene ambigua is represented by two locule casts, with incomplete endocarp wall. This species shows multiple features uniting it with genera of the Phytocreneae tribe of Icacinaceae: endocarps bisymmetrical, unilocular, with numerous surface pits corresponding to tuberculate protrusions into the locule cavity. Reid and Chandler (1933) placed this in Palaeophytocrene because it shows clear affinities with the Phytocreneae tribe but preserves insufficient detail for more extensive comparisons with other modern and fossil taxa. The general form of $P$. ambigua is similar to that of $P$. foveolata but the former is distinguished in being smaller and having larger and fewer pits, with conical, rather than parallel-sided, extensions of the endocarp into the locule cavity. Our incomplete knowledge of the endocarp surface of $P$. ambigua (whether it contained ridges in addition to pits) makes it difficult to fully assess the taxonomic affinities of this fossil with genera of the Phytocreneae. However, as Reid and Chandler (1933) commented, several characters point to affinities with Miquelia, an extant 
genus that has yet to be documented in the fossil record. P. ambigua, like Miquelia, has broad sloping tubercles extending into the locule; this contrasts with the other modern Phytocreneae genera, which generally lack tubercles (Phytocrene), have longer, more parallel-sided tubercles (Pyrenacantha), or have only slight dimples on the inner endocarp wall (Stachyanthus), corresponding to pits on the surface. While Miquelia possesses fine papillae on the locule lining, unlike other Phytocreneae genera (Stull et al. 2012), the condition of the locule lining is unknown in P. ambigua. Given the absence of important character data (namely, the endocarp surface ornamentation and locule lining condition), it seems prudent to retain this species in Palaeophytocrene, recognizing its position within the Phytocreneae but uncertain affinities with the genera included in this tribe.

Perforatocarpum Stull, Adams, Manchester et Collinson, gen. nov.

Diagnosis: Endocarp obovate in lateral view, bisymmetrical, with numerous small pits ornamenting the endocarp surface. Pits correspond to small bumps projecting into the locule. Primary vascular bundle marginal, entering locule subapically; two canals (one on each lateral face) emerging from the vascular bundle at its point entry into the locule.

Type species: Perforatocarpum echinatum (Chandler) Stull, Adams, Manchester et Collinson. Etymology: Derived from the Latin word "perforatus," which means "pierced" or "penetrated," in reference to the small pits, or perforations, covering the endocarp surface.

Remarks: This genus shows clear affinities with the Phytocreneae tribe but exhibits a distinctive combination of characters not found in any known fossil or modern genus. At present, it accommodates a single species, Perforatocarpum echinatum, previously placed in Icacinicarya. 
Perforatocarpum echinatum (Chandler) Stull, Adams, Manchester et Collinson, comb. nov. Fig. 9.

Basionym: Icacinicarya echinata Chandler (1961; pl. 22, figs. 41, 42).

Emended specific diagnosis: Endocarp pointed-obovate in lateral view, sharply angled at the margin, lenticular in transverse section. Endocarp surface ornamented with densely spaced, irregularly arranged small pits. Endocarp base asymmetrical. Length (as preserved) $11.5 \mathrm{~mm}$; width $7.5 \mathrm{~mm}$; thickness $5 \mathrm{~mm}$.

Holotype: V30182 (Fig. 9), originally figured by Chandler (1961; pl. 22, figs. 41, 42).

Specimen scanned: V30182 (holotype).

Description: Endocarp bisymmetrical (Fig. 9D-F), unilocular, obovate in lateral view (Fig. 9A-

C), lenticular in transverse section (Fig. 9G), with a sharply angled margin and a slightly pointed apex (Fig. 9A-C). Endocarp densely covered with small pits, represented by pyrite infillings projecting from the abraded endocarp wall (e.g., Fig. 9E); only the inner endocarp wall is preserved over most of the surface, thus the pyrite infillings of the pits appear as projections. Surface pits correspond to small bumps on the locule surface (represented by dimples on the locule cast; Fig. 9B, E, F). Primary vascular bundle entirely abraded except for a small portion near the apex (Fig. 9B, C, F), indicating that the course was marginal in the plane of symmetry. Endocarp with two subapical channels (represented as horn-like structures) flanking the stylar canal, emerging from the vascular bundle at its point of entry into the locule (Fig. 9F). Endocarp (as preserved) $11.5 \mathrm{~mm}$ in length, $7.5 \mathrm{~mm}$ in width, and $5 \mathrm{~mm}$ in thickness.

Remarks: This species shows features consistent with the Phytocreneae tribe (e.g., pitted endocarps) but a distinctive combination of characters not found in any particular modern or fossil genus. The endocarp surface of this species is covered with numerous small pits, similar to 
species of Pyrenacantha and Stachyanthus. Also, like Stachyanthus, the pits appear to correspond to tubercles that extend very shallowly into the locule (forming small dimples on the locule cast; Fig. 9C). However, in contrast with Stachyanthus and Pyrenacantha, this species appears to possess a marginal primary vascular bundle that enters the endocarp subapically, with a pair of channel-like structures emerging from the vascular bundle (Fig. 9B, C, F). In Stachyanthus and Pyrenacantha, the entrance of the vascular bundle is strictly apical, without any associated channel-like structures. The species is distinct from Miquelia, Phytocrene, and Palaeophytocrene in having much smaller pits. Given that Icacinicarya serves as a repository for poorly understood fossils of Icacinaceae, we decided to establish a new fossil genus for this species, to highlight its distinct features and affinity with the Phytocreneae tribe (which were obscured by its former placement in Icacinicarya). We note similarities in endocarp size and spacing of pits to the species known as Icacinicarya densipunctata from the Messel flora (Collinson et al. 2012). However, the locule surface details and vasculature are not yet known for the Messel specimens. While the Messel taxon also clearly represents Phytocreneae, its precise generic affinity, e.g., with Pyrenacantha or Perforatocarpum, remains uncertain.

Stizocarya Reid and Chandler emend. Stull, Adams, Manchester et Collinson. Emended generic diagnosis: Endocarp obscurely bisymmetrical, pitted externally. Pits (or channels) cylindrical, narrow, spanning from the endocarp surface to the locule lining; tuberculate projections into the locule absent. Locule lining composed of equiaxial digitate cells. Vascular bundle marginal, embedded within the endocarp wall for most of its length, associated with a pair of knobs/canals at the endocarp apex.

Type species: Stizocarya communis Reid et Chandler. 
Stizocarya communis Reid et Chandler emend. Stull, Adams, Manchester et Collinson Fig. 10 .

Emended specific diagnosis: Endocarp sub-globose or ovoid in lateral view, ca. 11-14.5 mm in diameter. Endocarp wall thick $(1.5-2 \mathrm{~mm})$, perforated by numerous narrow cylindrical pits or channels. Channels span the entire thickness of the endocarp wall, terminating at the locule lining. Locule lining composed of large, interlocking digitate cells with their long axes periclinal to the locule. Seed with testa cells much inflated $0.025 \mathrm{~mm}$ in diameter.

Holotype: V22647, originally figured by Reid and Chandler (1933; pl. 15, figs. 35, 42).

Specimen scanned: V22647 (holotype); V22649 (most complete specimen; Fig. 10), figured by Reid and Chandler (1933; pl. 15, fig. 37).

Description: Endocarp approximately bisymmetrical (Fig. 10A-C), unilocular, globular or ovoid in lateral view, with a thick wall $(1.5-2 \mathrm{~mm})$ composed of numerous layers of digitate sclereids. Cells of endocarp wall form distinct layers (Fig. 10O). Locule lined with interlocking equiaxial star-shaped cells, approximately three to four cell-layers deep. Endocarp wall penetrated by narrow cylindrical pits/channels spanning from the external surface to the locule cavity; the channels appear to broaden slightly at the inner end. Tuberculate extensions into the locule absent. Style apical, flanked by two channels or ducts (represented as knobs on locule casts) emerging from the primary vascular bundle (Fig. 10E-G), which runs from the base to the apex within the endocarp wall (Fig. 21M). Endocarp 11-14.5 $\mathrm{mm}$ in diameter; greatest diameter of locule 9-13 $\mathrm{mm}$.

Remarks: This species is a common component of the flora of the London Clay Formation but only occurs at Sheppey, represented by ca. 180 specimens that have suffered various levels of 
abrasion, creating considerable variation in the appearance of each specimen. Some specimens (e.g., V22649 in Fig. 10A-L) appear to be covered with outwardly projecting extensions or tubercles, but these likely represent infills of narrow channels (Fig. 10M-O). When the carbonaceous endocarp wall has eroded away, these more resistant pyritized channel infillings remain, appearing as truncated tubercles (Reid and Chandler 1933). Although Reid and Chandler (1933) noted that long hairs occurred within the channels of the endocarp, emerging form the locule lining, our observations of the $\mu \mathrm{CT}$ imagery (Fig. 10D, L, N) and physical sections (Fig. $10 \mathrm{M}, \mathrm{O})$ did not corroborate this inference. Given these considerations, the fossils therefore show similarity to the Phytocreneae tribe of Icacinaceae, in having endocarps covered with surface pits/channels. However, this species also shows important differences from other Phytocreneae fruits. For example, the globose shape is uncommon within the Phytocreneae tribe). The pits are also unusual; in Phytocreneae fruits, usually the pits correspond to the protrusions into the locule, while in S. communis the pits simply represent channels that terminate before the locule lining. Phytocrene fruits often have pits terminating before the locule cavity, but in S. communis the endocarp is unusually thick compared to the narrowness of the channels scattered throughout. The position of the vascular bundle embedded within the endocarp wall (as indicated by Reid and Chandler 1933) is also a distinction from fruits of extant Phytocreneae. The presence of two channels or ducts emerging from the primary vascular bundle, flanking the stylar canal, is consistent with Icacinaceae in general. Despite resemblance with the Phytocreneae, this species possesses numerous distinct features warranting placement in its own fossil genus.

Stizocarya oviformis Reid et Chandler, which was not scanned for this study, is similar to S. communis in most features but distinguished in being smaller and broader in form. S. oviformis 
is known only from a single specimen (V22659, a locule cast with fragmentary remains of the endocarp; pl. 16, figs. 1, 2 in Reid and Chandler 1933) and perhaps simply constitutes a distorted or unusual individual of S. communis.

A phytocrenoid endocarp from the Messel flora, assigned to Icacinicarya sp. by Collinson et al. (2012; pl. 20, figs. a-c), resembles S. communis in overall size, shape and spacing of tubercles. This specimen is preserved as a compression fossil, with clear details of external endocarp surface, but with internal structure hidden from view. More information is needed - e.g., from $\mu \mathrm{CT}$ scans of the Messel specimen - to learn whether the similarities with Stizocarya are more than superficial.

\section{Icacinicarya Reid et Chandler}

Generic diagnosis: A fossil-genus to include species possessing endocarps and seeds showing the generic characters of Icacinaceae (see Reid and Chandler 1933, p. 322), but which cannot be related definitely to any particular genus or section of the family.

Type species: Icacinicarya platycarpa Reid and Chandler (designated by Manchester 1994, p. 53).

Remarks: Reid and Chandler established Icacinicarya to accommodate fossils conforming to the family but lacking sufficient diagnostic characters for assignment to any particular genus or tribe within the family. Recent phylogenetic studies (e.g., Kårehed 2001; Byng et al. 2014; Stull et al. 2015) have greatly refined our circumscription of the family as well as our understanding of relationships within it. Traditionally, the family included ca. 54 genera and 400 species; now the family includes 23 genera and ca. 150 species (Stull et al. 2015). Therefore, the fruit characters described for the traditional Icacinaceae do not necessarily represent diagnostic characters for the 
current, more exclusive circumscription of the family. Several genera now excluded from Icacinaceae - for example, Calatola, Dendrobangia, Poraqueiba-possess many of the characters outlined by Reid and Chandler (1933) for the family. Consequently, someparticularly poorly preserved — fossils attributed to Icacinicarya cannot be confirmed as representatives of Icacinaceae as currently circumscribed. Icacinicarya should therefore be viewed as a repository for fossils showing the general characters of the traditional Icacinaceae but lacking sufficient detail for assignment to clades within Icacinaceae, as currently circumscribed, or to taxa recently segregated from the family, e.g., genera of Metteniusaceae (Stull et al. 2015). Nevertheless, while fruit synapomorphies for Icacinaceae (sensu Stull et al. 2015) are unclear (which would permit distinction from recently removed taxa), there are multiple clades within the family that have diagnostic fruit characters (as noted in the Results section).

An exhaustive treatment of Icacinicarya is beyond the scope of this study. We have transferred one species of Icacinicarya (I. echinata) to a new genus, Perforatocarpum, to highlight its affinities with the Phytocrenae tribe (see above). Conversely, we transfer a species formerly treated as Iodes to Icacinicarya-Icacinicarya davisii (Chandler) Stull, Adams, Manchester et Collinson, comb. nov. - as it shows the general fruit characters of the family (as currently circumscribed) but lacks key diagnostic features of Iodes. We also provide brief descriptions and comments on the additional Icacinicarya species scanned, focusing on new details revealed through $\mu \mathrm{CT}$ imaging. Finally, of the eight Icacinicarya species not scanned (I. amygdaloidea, I. bognorensis, I. elegans, I. emarginata, I. jenkinsi, I. minima, I. mucronata, and I. ovoidea), we provide a brief taxonomic assessment based on the original figures and descriptions of Reid and Chandler (1933) and Chandler (1961). Particular focus is given to $I$. 
jenkinsi due to its similarity with the extant genus Miquelia, which was previously overlooked (Reid and Chandler 1933). The reasons for excluding each of these eight species from $\mu \mathrm{CT}$ scanning are presented in Appendix A1.

Icacinicarya davisii (Chandler) Stull, Adams, Manchester et Collinson, comb. nov.

Fig. 11 .

Basionym: Iodes davisi Chandler 1961 (pl. 22, figs. 7-9). The original specific epithet, davisi, was indicated with one " $\mathrm{i}$ " at the end. However, we have emended this to davisii following Recommendation $60 \mathrm{C} .1 \mathrm{~b}$ of the International Code of Nomenclature for algae, fungi, and plants (ICN; McNeill et al. 2012): "if the personal name ends with a consonant (but not in -er), substantival epithets are formed by adding $-i$ - (stem augmentation) plus the genitive inflection appropriate to the sex and number of the person(s) honoured", i.e., davis-ii for Davis (m). Original Diagnosis: Endocarp ovate in outline; surface with a network of sunk fibers (not raised as in I. multireticulata), stylar canal without a transverse rimmed aperture or flanking 'horn-like' projections. Length, $12.5 \mathrm{~mm}$; breadth, $8.5 \mathrm{~mm}$. Length of seed, $6.5 \mathrm{~mm}$; breadth, $5 \mathrm{~mm}$. Holotype: V30140 (Fig. 4), originally figured by Chandler (1961; pl. 22, figs. 7-9). Specimen scanned: V30140 (holotype).

Description: Endocarp bisymmetrical (Fig. 11C, D), bivalved, unilocular, ovate in lateral view (Fig. 11A, B, F, G), lenticular in transverse section (Fig. 11J-L). Endocarp surface somewhat smooth (Fig. 11A-G), ornamented with a network of fibers sunken in the endocarp surface (i.e., not raised ridges as occurs in other species of Icacinaceae). Primary vascular bundle travels along one margin (Fig. 11A, D, E, H, J), outside the endocarp wall, entering the locule subapically (Fig. 11H), where it supplies the apical, anatropous seed. Style apical, flanked by a 
pair of small pores/canals (Fig 11H), which connect to the primary vascular bundle near the apex, where it enters the locule cavity. Locule lining papillate; papillae ca. $0.025 \mathrm{~mm}$ in diameter, closely spaced (Chandler 1961).

Remarks: This species is based on a single specimen, collected at the London Clay locality of Bawdsey, Suffolk (Chandler 1961). The species was originally assigned to Iodes based on the presence of papillae on the locule lining and the general features of the endocarp. However, it has been noted that several other genera in Icacinaceae contain one or more species with papillae lining the locule, including Hosiea Hemsl. et E.H. Wilson and Miquelia. Additionally, some of the features shared between the fossil and Iodes (e.g., subapical pores flanking the style, connected to the primary vascular near the apex) occur in other genera in the family (e.g., Desmostachys Planch., Rhyticaryum Becc.). The fossil is distinct from Iodes in having sunken fibers, rather than raised ridges, ornamenting the endocarp surface. Finally, although Chandler (1961) described the vascular bundle of this species as embedded within the endocarp, the $\mu \mathrm{CT}$ images show that the vascular bundle actually travels outside the endocarp wall for most of its length. This combination of characters excludes this species from the genus Iodes but, at the same, makes it difficult to place elsewhere within the family. We therefore place this species within the fossil genus Icacinicarya, as I. davisii, underlining its affinities with Icacinaceae but uncertain placement within the family.

\section{Icacinicarya forbesii Chandler}

Fig. 12.

Holotype: V30180, originally figured by Chandler (1961, pl. 22, figs. 35-38).

Specimen scanned: V30180 (holotype). 
Description: Endocarp bisymmetrical, unilocular, oval to obovate in lateral view, lenticular in transverse section, with a thick endocarp wall ornamented with ridges. Ridges prominent, relatively parallel-sided, separated by deep grooves. Endocarp 26-28 mm in length, $21 \mathrm{~mm}$ in width, and $12.5 \mathrm{~mm}$ in thickness. Locule lining and seed not preserved.

Remarks: Although the surface of the endocarp appears nodular (Fig. 12A, B), rather than ridged, this is an artifact of preservation, as revealed by the $\mu \mathrm{CT}$ images (Fig. 12C-F). Pyrite has filled in the spaces between the ridges, and as the less resistant ridges have worn away, this has given the appearance of protruding nodules (Chandler 1961). The endocarp construction and surface ornamentation are therefore characteristic of Icacinaceae. However, many additional characters (e.g., the presence or absence of papillae, or the features of the seed, which is not preserved) are unknown.

\section{Icacinicarya glabra Chandler}

Fig. 13.

\section{Holotype: V30188.}

Specimen scanned: V30188 (holotype).

Description: Endocarp bisymmetrical, oval in lateral view, lenticular in transverse section.

Endocarp surface apparently smooth. Endocarp wall relatively thin $(0.4 \mathrm{~mm}$ as preserved).

Vascular bundle marginal, traveling outside the endocarp wall, entering the locule subapically.

Endocarp $13.5-14 \mathrm{~mm}$ in length, 7.5-9 $\mathrm{mm}$ in width, $4.5-5.25 \mathrm{~mm}$ in thickness.

Remarks: This species possesses the general fruit features of Icacinaceae but lacks distinctive/diagnostic features, thus precluding assignment to a particular clade within Icacinaceae. However, the smooth endocarp surface (if not an artifact of preservation) is 
somewhat unique, as relatively few species in the family have somewhat smooth endocarps (e.g., Casimirella spp., Leretia cordata Vell., Sarcostigma paniculata Pierre). Chandler (1961) noted that this species is similar to Icacinicarya platycarpa but smaller in size.

\section{Icacinicarya nodulifera Reid et Chandler}

Fig. 14.

Holotype: V22706.

Specimen scanned: V22706 (holotype).

Description: Endocarp bisymmetrical, unilocular, oval in lateral view, lenticular in transverse section. Endocarp surface uncertain; the smooth surface (Fig. 14D) might be an artifact of abrasion and/or pyrite decay. The locule cast (Fig. 14C) is coarsely ridged/faceted, suggesting that the endocarp surface (which generally reflects the shape of the locule cast) maybe have been ridged as well. Vascular bundle marginal, apparently embedded within the endocarp wall (Reid and Chandler 1933). Endocarp ca. $14 \mathrm{~mm}$ in length, $13 \mathrm{~mm}$ in width, 8 in thickness. Locule lining condition unknown.

Remarks: This species is poorly preserved and difficult to assess taxonomically, although its general features match Icacinaceae. Reid and Chandler (1933) noted that this species resembles their Iodes eocenica, with the latter being distinguished by a more compressed/lenticular form and a distinctly ridged (rather than nodular) endocarp surface. An embedded vascular bundle (noted by Reid and Chandler 1933) further supports affinities with Iodes. The position of the vascular bundle was ambiguous in the $\mu \mathrm{CT}$ scans; the longitudinal video sequence (http://dx.doi.org/10.5061/dryad.706df) appears to show an embedded vascular bundle, while in the transverse video sequence (http://dx.doi.org/10.5061/dryad.706df) the vascular bundle is not 
readily apparent. The endocarp surface of this species (as noted in the description) is also ambiguous, making comparisons with Iodes difficult. The affinities of this species are therefore uncertain; hence it is best retained in Icacinicarya.

\section{Icacinicarya ovalis Reid et Chander}

Fig. 15.

Holotype: V22702.

Specimen scanned: V22702 (holotype).

Description: Endocarp bisymmetrical (Fig. 15B, C), unilocular, oval in lateral view (Fig. 15A, D), lenticular in cross section (Fig. 15E-I). Endocarp surface covered with low, rounded ridges, encircling small concavities (Fig. 15A); a thick smooth ridges encircles the endocarp in the plain of symmetry (Fig. 15B). Endocarp wall thick, composed of interlocking digitate cells. Vascular bundle not embedded within the endocarp wall; it is inferred to have run outside the wall along one margin (Fig. 15F-I). Endocarp ca. 14-15 in length, $12 \mathrm{~mm}$ in width. Locule lining not papillate.

Remarks: The species does not show clear affinities with any particular genus or clade, although it does show the general fruit features of the family. In some respects, this species is similar to Icacinicarya collinsonae Pigg, Manchester et DeVore, from the Paleocene of western North America (Pigg et al. 2008). Both species have notably thick endocarp walls, composed of digitate cells, with a thick, rounded ridge encircling the endocarp in the plane of symmetry. The surface of the Paleocene species, however, is shallowly furrowed (figs. 7-9 in Pigg et al. 2008) rather than ridged with distinctive small concavities encircled by the ridges. 


\section{Icacinicarya platycarpa Reid and Chandler}

Fig. 16.

Holotype: V22686.

Specimen scanned: V22686 (holotype).

Description: Endocarp bisymmetrical (Fig. 16D, E), unilocular, elongate-oval in lateral view

(Fig. 16A-C), lenticular in transverse section (highly compressed; Fig. 16F-I). Endocarp surface covered with a reticulum of ridges (reflected on the locule casts; Fig. 16A-C). Position of the vascular bundle unknown; the endocarp is rarely preserved and most specimens are locule casts. Endocarp (as preserved) ca. 16-26 mm in length, $11.5-21 \mathrm{~mm}$ in width, $10 \mathrm{~mm}$ in thickness. Locule lining not papillate.

Remarks: This species, which was selected as the type species for the genus (Manchester 1994) has unclear affinities within the family. Reid and Chandler (1933) noted a superficial resemblance to Sarcostigma Wight et Arn., as well as to Iodes multireticulata. But I. platycarpa has notable differences from both of these taxa. It is also incompletely preserved. The lack of endocarp wall preservation makes more extensive comparisons across the family difficult.

\section{Icacinicarya reticulata Chandler}

Fig. 17.

Holotype: V30167.

Specimen scanned: V30167 (holotype).

Description: Endocarp bisymmetrical (Fig. 17A, B), unilocular, oval in lateral view (Fig. 17C, D), sub-globose in transverse section (Fig. 17E). Endocarp surface covered with a network of thick fibers and/or vasculature partially embedded in the endocarp wall (Fig. 17A-D). The 
endocarp wall is relatively thick $(2-3.5 \mathrm{~mm})$ and composed at least partially of interlocking digitate cells. Vascular bundle marginal, positioned outside the endocarp wall. Endocarps (as preserved) $13.5-16 \mathrm{~mm}$ in length, $15-17 \mathrm{~mm}$ in width, 11-12.5 $\mathrm{mm}$ in thickness. Locule lining not papillate.

Remarks: Several genera of Icacinaceae include endocarps covered with a network of sunken fibers (e.g., Icacina A. Juss.) similar to Icacinicarya reticulata. However, additional features linking this fossil species to any particular modern genus are unclear.

\section{"Icacinicarya sp. 12"}

Not figured.

Specimen scanned: V22726.

Description: Endocarp oval in lateral view, with an irregularly nodular/ridged surface ornamentation. Vascular bundle marginal. Locule lining with interlocking digitate cells. Endocarp $7 \mathrm{~mm}$ in length, $5.6 \mathrm{~mm}$ in width, $5.3 \mathrm{~mm}$ in thickness.

Remarks: The features documented for the specimen are consistent with Icacinaceae; however, distinctive or diagnostic features are absent that might permit a more refined systematic placement, or a more detailed comparison with other fossil taxa to assess conspecificity. The $\mu \mathrm{CT}$ imaging of this specimen did not reveal any additional useful character data. We therefore did not include a figure in the text, although the $\mu \mathrm{CT}$ images are available on dryad (http://dx.doi.org/10.5061/dryad.706df).

\section{Incertae Sedis}


The following taxa either do not belong to Icacinaceae, as revealed by the $\mu \mathrm{CT}$ imagery, or lack sufficient preservation for confident assignment to Icacinaceae. We therefore label them as incertae sedis. Additional work will be necessary to identify their true systematic affinities.

\section{“Icacinicarya” foveolata Reid et Chandler}

Fig. 18.

Holotype: V22710.

Specimen scanned: V22710 (holotype).

Description: Endocarp unilocular, bisymmetrical, ovoid in lateral view, with a thick endocarp

wall (Fig. 18B, C, F) composed largely of sinuous to digitate cells. Endocarp surface smooth (as preserved; Fig. 18C), with a finely tiled or tessellated appearance caused by the hexagonal cells making up the outer layer. Endocarp $14-15 \mathrm{~mm}$ in length, $11 \mathrm{~mm}$ in width, and 9-10 $\mathrm{mm}$ in thickness.

Remarks: Although similar to Icacinaceae in several respects (endocarps unilocular, bisymmetrical, with the wall composed, at least partially, of sinuous to digitate cells), this species also has notable differences. Reid and Chandler (1933) noted that this species has large hexagonal secretory cells lining the outside of the seed; this is not known in any modern species of the family. The endocarp wall is also notably thick, and the endocarp surface (as preserved) is smooth with a "finely tessellated appearance" caused by hexagonal cells on the surface (p. 350, Reid and Chandler 1933); these features are also unusual in Icacinaceae. These distinctions suggest that this species probably does not belong to the family.

\section{"Icacinicarya sp. 11"}


Fig. 19A-G.

Specimen scanned: V22725.

Description: Endocarp bisymmetrical (Fig. 19D), unilocular, oval to roundly quadrangular in lateral view (Fig. 19A-C), lenticular in transverse section. Endocarp surface smooth (as preserved; Fig. 19A-C). Endocarp wall composed of compact sclerenchyma cells. Length (as preserved; endocarp broken) $18 \mathrm{~mm}$, width $25 \mathrm{~mm}$, thickness $15 \mathrm{~mm}$ ).

Remarks: This "species" is represented by a single broken endocarp. Several features shown by this fossil (e.g., the slightly quadrangular shape and smooth endocarp surface) are unusual for Icacinaceae. The worn, poorly preserved condition makes more detailed comparisons with fossil and modern members of Icacinaceae somewhat difficult. Study of better-preserved, newly collected specimens might clarify the affinities of this species.

\section{“Icacinicarya rotundata" (Bowerbank) Reid et Chandler}

Fig. 19H-J.

Holotype: Missing; originally figured by Bowerbank (1840; pl. 17, figs. 8, 9).

Specimen scanned: V22722 (best surviving specimen).

Remarks: This species is represented by poorly preserved locule casts. The $\mu \mathrm{CT}$ scans did not reveal any useful character information beyond the brief details noted by Reid and Chandler (1933). Additional research on better-preserved, newly collected specimens will be necessary to clarify the systematics of this species.

\section{Species not scanned}


Of the eight Icacinicarya species not scanned for this study, we accept six (I.

amygdaloidea, I. elegans, I. emarginata, I. jenkinsi, I. minima, and I. ovoidea) as representatives of Icacinaceae based on the information presented by Reid and Chandler (1933) and Chandler (1961). These species exhibit many of endocarp features characteristic of Icacinaceae (noted in the Results section). The other two species (I. bognorensis and I. mucronata) are based on single locule casts with little endocarp preserved. Many important features (e.g., the course of the vascular bundle, the presence of subapical canals, the endocarp surface ornamentation, the path of the raphe along the seed) are therefore not preserved, making it difficult to confirm these as representatives of Icacinaceae.

Of the accepted species, Icacinicarya jenkinsi (Fig. 8I) is of particular interest because it shares many similarities with Miquelia, an extant genus yet to be documented in the fossil record. Miquelia is today restricted to Indo-Malesia. Endocarps of the genus are characterized by broad surface pits that corresponding to conical tubercles extending somewhat shallowly into the locule. The surface has ridges, sometimes sharply crested, encircling the pits; these ridges are often slightly reflected on the inner endocarp surface, surround the tubercles. While the pitting can appear irregularly arranged, the tubercles occur in neat vertical columns. The locule lining is also distinctly papillate. Endocarps range from ca. $10-25 \mathrm{~mm}$ in length and 6-16 $\mathrm{mm}$ in width; in general they are notably smaller than Phytocrene, its sister genus.

The fossil of Icacinicarya jenkinsi, much like Miquelia, has broad, conical tubercles extending shallowly into the locule (inferred from pits on locule cast), with an even spacing and regular arrangement. The locule lining is distinctly papillate. It's size — at least $10.5 \mathrm{~mm}$ in length, $5.6 \mathrm{~mm}$ in width; these are the dimensions of the locule cast —is also consistent with Miquelia. Therefore, all of its known features are consistent with this extant genus. However, the 
endocarp surface ornamentation (whether it had ridges in addition to pits) is incompletely known. Because of this, we hesitate to officially transfer this fossil to Miquelia, although it clearly has close affinities with this genus.

\section{Discussion}

The London Clay Formation includes the greatest diversity of Icacinaceae known from any fossil assemblage (e.g., Manchester 1994; Collinson et al. 2012), and therefore provides important insight onto the evolutionary history of the family. The flora includes some of the earliest evidence of the extant genus Iodes (represented here by four species), which has a rich fossil history in the Northern Hemisphere contrasting with its present confinement to the Old World tropics. Iodes is the only extant genus of Icacinaceae now recognized in the flora from the London Clay Formation, and its fossil history is discussed in greater detail below.

The diversity of extinct genera of Icacinaceae in the London Clay Formation is also notable (Pigg and DeVore 2005). Some of these taxa show relatively close affinities with extant genera, while others possess distinctive morphological features suggesting phylogenetic isolation from extant genera. Comparison of the fossils from the London Clay Formation with Icacinaceae taxa from other fossil and modern floras also provides important biogeographic insights about the family. These points are considered in greater detail below.

Fossil history of Iodes - The fossil history of Iodes (summarized by Allen et al. 2015) includes numerous records from the Paleogene of the Northern Hemisphere. In North America, three species have been recognized to date: I. multireticulata, from the Eocene Clarno Formation of Oregon (Manchester 1994) and the Eocene Nanjemoy Formation of Virginia (Tiffney 1999); I. 
chandlerae Manchester from the Eocene Clarno Formation (Manchester 1994); and I.

occidentalis S.E. Allen, Stull et Manchester from the Eocene Bridger Formation ( 49.5 Ma) of southwestern Wyoming (Allen et al. 2015). I. chandlerae, however, is based on locule casts, making it impossible to assess the vascular bundle position, a key characteristic of Iodes, until more complete material becomes available.

With the transfer of Biceratocarpum brownii to Iodes, herein, there are now four species of Iodes recognized in North America. However, several additional taxa, attributed to the fossil genera Iodicarpa (I. ampla Manchester and I. lenticularis Manchester) and Croomiocarpon (C. mississippiensis Stull, Manchester et Moore), show the key diagnostic features of Iodes and perhaps belong in this modern genus (Allen et al. 2015). This would raise the number of Iodes species recognized in North America to seven.

Based on the results presented in this paper, we recognize four species of Iodes from the London Clay Formation: I. bilinica, I. corniculata, I. eocenica, and I. multireticulata. For the latter two species, we were unable to verify the position of the vascular bundle (due to abrasion/degradation of the samples examined). However, the original observations of Reid and Chandler (1933) indicated that the vascular bundle ran within the endocarp wall along one margin, consistent with Iodes. We therefore accept the original treatments of Reid and Chandler (1933) pending additional information.

Iodes bilinica has a complicated nomenclatural and taxonomic history (discussed in the Systematics section). The fossils included under this name have been attributed variously, by different authors, to Amygdalus of Rosaceae and the icacinaceous genera Hosiea, Natsiatum, and Palaeohosiea. Based on our observations, the fossils match Iodes in all key characteristics (e.g., endocarp surface sculpture, position of vascular bundle, presence of papillae), indicating that the 
species belongs in this extant genus. The formerly recognized extant genus Polyporandra Becc. also possesses the endocarp features and phylotaxy of Iodes, and was subsumed within Iodes when it was found to be nested within that genus based on molecular sequence data (Byng et al. 2014).

A fossil fruit from the Upper Cretaceous (Maastrichtian) of Israel was also attributed to Iodes by Soudry and Gregor (1997), as Iodes israelii. However, the position of the vascular bundle has not been confirmed in this specimen, making it difficult to assess whether or not this fossil truly belongs in the genus. There are no published reports of Iodes fossil fruits from Africa or Asia, where the genus occurs today, although a fossil fruit possibly representing Iodes has recently been recovered from the Miocene Wenshan flora of southeastern Yunnan (Zhekun Zhou, pers. comm.; Stull et al. 2014)

In total, five species have been documented and confidently identified to the genus from the fossil record (Iodes bilinica, I. brownii, I. corniculata, I. eocenica, I. multireticulata, and I. occidentalis; not including the locule casts of I. chandlerae), with an additional six species also possibly belonging to this genus (Croomiocarpon mississippiensis, Iodes chandlerae, Iodes israelii, Iodicarpa ampla, Iodicarpa lenticularis, unpublished cf. Iodes fossil from China). Of these records, the fossils from the London Clay Formation (dated to early Ypresian, those from Herne Bay ca. $52 \mathrm{Ma}$ ) represent the oldest confidently identified fossils of the genus. The oldest material from North America is ca. 49.5 Ma, derived from the Bridger Formation (Allen et al. 2015).

Biogeographic insights - Several of the taxa represented in the London Clay flora have interesting biogeographic connections with other fossil and modern floras. Iodes multireticulata, 
an abundant species in the London Clay Formation, has also been recognized from a few Eocene floras of North America. Iodes corniculata shows close morphological similarity with I. brownii from western North America (Allen et al. 2015; this paper), as both possess a pair of subapical horns and have well-defined ridge areoles generally lacking freely ending ridgelets. These species provide support for a strong floristic connection between Europe and North America during the early-middle Eocene, as has been suggested by other authors (e.g., Manchester 1994, 1999), perhaps facilitated by migration across the North Atlantic Land Bridge (Tiffney 1985). Among modern Iodes, to our knowledge, only a few species restricted to Southeast Asia possess a pair of subapical horns similar to those of I. brownii and I. corniculata. The size and surface sculpture of Iodes multireticulata, however, is more similar to several African species-e.g., Iodes africana Welw. ex Oliv., Iodes klaineana Pierre, Iodes seretii (De Wild.) Boutique - as Reid and Chandler (1933) originally noted. This suggests that Iodes (or at least certain lineages within the genus) may have originated in Europe or North America before migrating to various parts of the Old World tropics.

Palaeophytocrene, represented by two species in the London Clay flora, shows the strongest affinities with Phytocrene and Miquelia, which are sister genera confined today to Indo-Malesia. Fossils of Palaeophytocrene similar to the London Clay species have also been described from the Eocene of western North America (Scott 1954; Manchester 1994). Palaeophytocrene therefore shows a similar pattern to I. corniculata, with morphologically similar fossil taxa in the Eocene of western North America and modern relatives in Southeast Asia/Indo-Malesia.

While some of the taxa described from the London Clay-e.g., Faboidea, Perforatocarpum, Sphaerodes, and Stizocarya — are not known from any other fossil floras, 
several others have been documented from other English floras (e.g., Chandler 1962), as well as floras from Germany (Kvaček and Bůžek 1995; Collinson et al. 2012) and the Czech Republic (Kvaček, Z., and Bůžek, Č. 1995) indicating that some of the London Clay taxa were widespread across Europe during the Eocene.

Significance of extinct taxa-Fossils of Icacinaceae from the London Clay Formation span the breadth of fruit morphology shown by modern members of the family. For example, across the family, endocarp surfaces range from rugose, to ridged, to dimpled or pitted, to relatively smooth; all of these ornamentation types are represented in the fossil flora. Furthermore, the flora includes numerous taxa with distinct combinations of characters not found in any particular modern genus. In some cases, fossil genera/species appear closely related to extant clades (e.g., Sphaeriodes and Faboidea are perhaps related to Iodes). In others, however, the affinities with modern genera are less clear. Stizocarya, for example, appears to possess endocarp surface pits, consistent with the Phytocreneae clade, but this genus also possesses features (e.g., pits forming channels through the entire endocarp wall, with corresponding tubercles projecting into the locule) that make its affinities with particular modern lineages obscure. Given the considerable breadth of fruit morphologies present in the London Clay Formation-as well as the presence of presumably extinct, phylogenetically isolated lineages showing unusual features or combinations of characters - the flora is perhaps capturing the early diversification of major clades within the family (e.g., the Iodes clade, the Phytocreneae clade; Stull et al. 2015). However, convincing fossils of the family have been documented from the Paleocene of both North and South America. These fossils include pitted (i.e., Phytocreneae; Stull et al. 2012) as well as reticulately ridged endocarp types (uncertain placement within the family; Pigg et al. 2008). The crown of 
Icacinaceae had therefore begun to diversify, at least to some degree, before the Eocene. But the onset of hyperthermals during the early Eocene appears to have spurred significant diversification in the family, as indicated by diversity of Icacinaceae present in the London Clay and several other Eocene floras, such as the Nut Beds flora of Oregon (Manchester 1994) and the Messel flora of Germany (Collinson et al. 2012).

\section{Acknowledgements}

We thank Ashley A. Klymiuk, Selena Y. Smith, and Stefan A. Little for inviting the authors to participate in the colloquium honoring Ruth A. Stockey (at Botany 2015) and for organizing this special issue of Botany. We also thank Peta Hayes for curatorial assistance at NHMUK. GWS acknowledges support from NSF grant DEB-1310805 (Doctoral Dissertation Improvement Grant to SRM, PS Soltis, and GWS). NFA thanks the Palaeontological Association for the award of an Undergraduate Research Bursary (PA-UB201401). We thank the following curators and collection managers for facilitating our study of modern comparative material: Kent Perkins (FLAS), Timothy Utteridge (K), Zhou Zhekun (KUN), Gerard Thijsse (L, U), Jim Solomon (MO), Corinne Sarthou (P), and Jan Wieringa (WAG).

Formatted: Font: $12 \mathrm{pt}$

\section{References}

Allen, S.E., Stull, G.W., and Manchester, S.R. 2015. Icacinaceae from the Eocene of western North America. Am. J. Bot. 102(5): 725-744. doi:10.3732/ajb.1400550.

APG. 2016. An update of the Angiosperm Phylogeny Group classification for the orders and families of flowering plants: APG IV. Bot. J. Linn. Soc. 181(1): 1-20. doi:10.1111/boj.12385. 
Berry, E.W. 1930. A flora of Green River age in the Wind River Basin of Wyoming, 55-81. U.S. Geological Survey Professional Paper, 165-B. Washington, D.C., USA.

Bowerbank, J.S. 1840. A History of the Fossil Fruits and Seeds of the London Clay. John Van Voorst, London.

Byng, J.W., Bernardini, B., Joseph, J.A., Chase, M.W., and Utteridge, T.M.A. 2014. Phylogenetic relationships of Icacinaceae focusing on the vining genera. Bot. J. Linn. Soc. 176(3): 277-294. doi:10.1111/boj.12205.

Chandler, M.E.J. 1925. The Upper Eocene Flora of Hordle, Hants. Part 1. Monogr. Palaeontogr. Soc., Lond. 77(360): 1-32.

Chandler, M.E.J. 1961. The Lower Tertiary Floras of Southern England. I. Palaeocene Floras, London Clay Flora (Supplement). British Museum (Natural History), London.

Chandler, M.E.J. 1962. The Lower Tertiary Floras of Southern England. II. Flora of the PipeClay series of Dorset (Lower Bagshot). British Museum (Natural History), London.

Chandler, M.E.J. 1964. The Lower Tertiary Floras of Southern England. IV. A Summary and Survey of Findings in the Light of Recent Botanical Observations. British Museum (Natural History), London.

Chandler, M.E.J. 1978. Supplement to the Lower Tertiary floras of southern England, part 5. Tertiary Research Special Paper, 4: 1-47.

Cohen, K.M., Finney, S.C., Gibbard, P.L., and Fan, J.-X. 2013. The ICS International Chronostratigraphic Chart. Episodes, 36(3): 199-204.

Collinson, M.E. 1983. Fossil Plants of the London Clay. Palaeontological Association Field Guides to Fossils, No. 1. The Palaeontological Association, London. 
Collinson,M.E. and Cleal, C.J. 2001a. Early and early-middle Eocene (Ypresian-Lutetian) palaeobotany of Great Britain. p. 185-226. In Cleal, C.J., Thomas, B.A., Batten, D.J. \& Collinson, M.E. Mesozoic and Tertiary Palaeobotany of Great Britain, Geological Conservation Review Series, No 22, Joint Nature Conservation Committee, Peterborough. Collinson, M.E. and Cleal, C.J. 2001b. Late middle Eocene-early Oligocene (BartonianRupelian) and Miocene palaeobotany of Great Britain. p. 227-274. In Cleal, C.J., Thomas, B.A., Batten, D.J. \& Collinson, M.E. Mesozoic and Tertiary Palaeobotany of Great Britain, Geological Conservation Review Series, No 22, Joint Nature Conservation Committee, Peterborough

Collinson, M.E., Manchester, S.R., and Wilde, V. 2012. Fossil fruits and seeds of the Middle Eocene Messel biota, Germany. Abh. Senckenb. Naturforsch. Ges. 570: 1-249.

Collinson, M.E., Adams, N.F., Manchester, S.R., Stull, G.W., Herrera, F., Smith, S.Y., Andrew, M., Kenrick, P., and Sykes, D. 2016. Application of X-ray micro-computed tomography (micro-CT) to pyrite permineralized fruits and seeds from the London Clay Formation (Ypresian) conserved in silicone oil. Botany, this volume.

Engler, A. 1893. Icacinaceae In Die Natürlichen Pflanzenfamilien, Vol. 3. Edited by A. Engler and K.A. Prantl. Engelmann, Leipzig, Germany. pp. 233-257.

Ettingshausen, C. 1869. Die fossile Flora des Tertiärbeckens von Bilin, III. Denkschriften der Kaiserlichen Akademie der Wissenschaften Wien, Mathematisch-Naturwissenschaftliche Klasse, 29: 1-110.

Howard, R.A. 1940. Studies of the Icacinaceae. I. Preliminary taxonomic notes. J. Arnold Arbor. 21: 461-489. 
Howard, R.A. 1942a. Studies of the Icacinaceae. II. Humirianthera, Leretia, Mappia and Nothapodytes, valid genera of the Icacineae. J. Arnold Arbor. 23: 479-494.

Howard, R.A. 1942b. Studies of the Icacinaceae. IV. Considerations of hte New World genera. Contrib. Gray Herb. Harvard Univ. 142: 3-60.

Kårehed, J. 2001. Multiple origin of the tropical forest tree family Icacinaceae. Am. J. Bot. 88(12): 2259-2274.

Kvaček, Z., and Bůžek, Č. 1995. Endocarps and foliage of the flowering plant family Icacinaceae from the Tertiary of Europe. Tertiary Res. 15(3): 121-138.

Mai, D.H. 1980. Zur Bedeutung von Relikten in der Florengeschichte. In 100 Jahre Arboretum (1879-1979). Edited by W. Vent. Akademie-Verlag, Berlin. pp. 281-307.

Mai, D.H. 1987. Neue Früchte und Samen aus paläozänen Ablagerungen Mitteleuropas. Feddes Repert. 98(3-4): 197-229.

Mai, D.H., and Walther, H. 1978. Die Floren der Haselbacher Serie im Weisselster-Backen (Bezirk Leipzig, DDR). Abh. Staatl. Mus. Mineral. \& Geol. Dresden. 28: 1-101.

Manchester, S. R. 1994. Fruits and Seeds of the Middle Eocene Nut Beds Flora, Clarno Formation, Oregon. Palaeontogr. Am. 58: 1-205.

Manchester, S. R. 2011. Fruits of Ticodendraceae (Fagales) from the Eocene of Europe and North America. Int. J. Plant Sci. 172(9): 1179-1187. doi:10.1086/662135.

Manchester, S. R., Xiang, Q.-Y., and Xiang, Q.-P. 2007. Curtisia (Cornales) from the Eocene of Europe and its phytogeographical significance. Bot. J. Linn. Soc. 155(1): 127-134. doi:10.1111/j.1095-8339.2007.00680.x. 
Manchester, S. R., Xiang, X.-P., and Xiang, Q.-Y. 2010. Fruits of Cornelian Cherries (Cornaceae: Cornus subg. Cornus) in the Paleocene and Eocene of the Northern Hemisphere. Int. J. Plant Sci. 171(8): 882-891. doi:10.1086/655771.

McNeill, J., Barrie, F.R., Buck, W.R., Demoulin, V., Greuter, W., Hawksworth, D.L., Herendeen, P.S., Knapp, S., Marhold, K., Prado, J., Prud'homme van Reine, W.F., Smith, G.F., Wiersema, J.H., and Turland, N.J. 2012. International Code of Nomenclature for algae, fungi, and plants (Melbourne Code), adopted by the Eighteenth International Botanical Congress, Melbourne, Australia, July 2011. Regnum Veg. 154: 1-208.

Peng, H., and R.A. Howard. 2008. Icacinaceae. Pp. 505-514 in Flora of China. Vol. 11, eds. Z. Y. Wu, P. H. Raven, and D. Y. Hong. Beijing: Science Press and St. Louis: Missouri Botanical Garden Press.

Pigg, K.B., and DeVore, M.L. 2005. Paleoactaea gen. nov. (Ranunculaceae) fruits from the Paleogene of North Dakota and the London Clay. American Journal of Botany 92(10): $1650-1659$.

Pigg, K.B., Manchester, S.R., and DeVore, M.L. 2008. Fruits of Icacinaceae (tribe Iodeae) from the Late Paleocene of western North America. Am. J. Bot. 95(7): 824-832. doi:10.3732/ajb.2007340.

Rankin, B.D., Stockey, R.A., and Beard, G. 2008. Fruits of Icacinaceae from the Eocene Appian Way Locality of Vancouver Island, British Columbia. Int. J. Plant Sci. 169(2): 305-314. doi:10.1086/523876.

Reid, E.M., and Chandler, M.E.J. 1933. The London Clay flora. British Museum (Natural History), London. 
Scott, R.A. 1954. Fossil fruits and seeds from the Eocene Clarno Formation of Oregon. Palaeontologr. Abt. B. 96(3-6): 66-97.

Sieber, J. 1880. Zur Kenntnis der nordböhmischen Braunkohlenflora. Sitzungsberichte der Kaiserlichen Akademie der Wissenschaften, Mathematisch-Naturwissenschaftliche Klasse. 82: 67-101.

Sleumer, H. 1942. Icacinaceae. In Die Natürlichen Pflanzenfamilien, Vol. 20b. Edited by A. Engler. Engelmann, Leipzig, Germany. pp. 322-396.

Smith, S.Y., Collinson, M.E., Simpson, D.A., Rudall, P.J., Marone, F., and Stampanoni, M. 2009. Virtual taphonomy using synchrotron tomographic microscopy reveals cryptic features and internal structure of modern and fossil plants. Proc. Natl. Acad. Sci. USA. 106(29): 12013-12018. doi:10.1073/pnas.0901468106.

Soltis, D.E., Soltis, P.S., Chase, M.W., Mort, M.E., Albach, D.C., Zanis, M., Savolainen, V., et al. 2000. Angiosperm phylogeny inferred from $18 \mathrm{~S}$ rDNA, rbcL, and atpB sequences. Bot. J. Linn. Soc. 133(4): 381-461. doi:10.1111/j.1095-8339.2000.tb01588.x.

Soltis, D.E., Smith, S.A., Cellinese, N., Wurdack, K.J., Tank, D.C., Brockington, S.F., RefulioRodriguez, N.F., et al. 2011. Angiosperm phylogeny: 17 genes, 640 taxa. Am. J. Bot. 98(4): 704-730. doi:10.3732/ajb.1000404.

Soudry, D., and Gregor, H.-J. 1997. Jodes israelii sp. nov.: a huge phosphate-mineralized icacinacean fructification from the Late Cretaceous of the Negev, southern Israel. Cretaceous Res. 18(2): 161-178.

Stevens, P.F. 2001 onwards. Angiosperm Phylogeny Website. Version 12, July 2012 [and more or less continuously updated since]. Available from http://www.mobot.org/MOBOT/research/APweb [accessed 31 January 2016]. 
Stull, G.W., and Manchester, S.R. 2012. Fossils of the tribe Iodeae (Icacinaceae) from North and South America. Botanical Society of America Abstract No. 736, Botany 2012. Columbus, Ohio, 7-11 July. Available from http://2012.botanyconference.org/engine/search/index.php?func=detail\&aid=736 [accessed 31 January 2016].

Stull, G.W., Moore, R., and Manchester, S.R. 2011. Fruits of Icacinaceae from the Eocene of Southeastern North America and Their Biogeographic Implications. Int. J. Plant Sci. 172(7): 935-947. doi:10.1086/660877.

Stull, G.W., Herrera, F., Manchester, S.R., Jaramillo, C., and Tiffney, B.H.. 2012. Fruits of an “Old World" tribe (Phytocreneae; Icacinaceae) from the Paleogene of North and South America. Syst. Botany, 37(3): 784-794. doi: 10.1600/036364412X648724.

Stull, G.W., Allen, S.E., and Manchester, S.R. 2014. Fossils of Iodes (Icacinaceae) from the early Eocene Blue Rim flora (SW Wyoming) and the late Miocene Wenshan flora (SW Yunnan, China). Paleontol. Soc. Spec. Publ. 13: 17-18.

Stull, G.W., Duno de Stefano, R., Soltis, D.E. and Soltis, P.S.. 2015. Resolving basal lamiid phylogeny and the circumscription of Icacinaceae with a plastome-scale data set. Am. J. Bot. 102(11): 1794-1813. doi:10.3732/ajb.1500298.

Takhtajan, A. 1966. Major phytochorias of the Late Cretaceous and the Early Tertiary on the territory of the U.S.S.R. and adjacent countries. Botanicheskij Zhurnal 51: 1217-1230.

Tiffney, B.H. 1985. The Eocene North Atlantic land bridge: its importance in Tertiary and modern phytogeography of the Northern Hemisphere. J. Arnold Arbor. 66(2): 243-273.

Tiffney, B.H. 1999. Fossil fruit and seed flora from the Early Eocene Fisher/Sullivan site. In Early Eocene Vertebrates and Plants from the Fisher/Sullivan Site (Nanjemoy 
Formation), Stafford County, Virginia. Edited by S.J. Johnson. Virginia Division of Mineral Resources Publication, Charlottesville, Virginia, USA. pp. 139-159.

Weeks, A., Zapata, F., Pell, S.K., Daly, D.C., Mitchell, J.D., and Fine, P.V.A. 2014. To move or to evolve: contrasting patterns of intercontinental connectivity and climate niche evolution in "Terebinthaceae" (Anacardiaceae and Burseraceae). Front. Genet. 5: 409. doi:10.3389/fgene.2014.00409.

Zachos, J., Pagani, M., Sloan, L., Thomas, E., and Billups, K. 2001. Trends, rhythms, and aberrations in global climate 65 Ma to present. Science, 292(5517): 686-693. doi:10.1126/science. 1059412.

Zachos, J.C., Dickens, G.R., and Zeebe, R.E. 2008. An early Cenozoic perspective on greenhouse warming and carbon-cycle dynamics. Nature, 451(7176): 279-283. doi:10.1038/nature06588. 
Table 1. Species of Icacinaceae from the London Clay Formation in the collections of the Natural History Museum, London (NHMUK), selected for $\mu \mathrm{CT}$ scanning, showing the rationale for specimens chosen where holotypes were missing or too degraded for study.

An asterisk indicates a specimen not figured here but figured in Collinson et al. (2016; this volume).

\begin{tabular}{|c|c|c|c|}
\hline Species & $\begin{array}{l}\text { NHMUK } \\
\text { collection number }\end{array}$ & Holotype & $\begin{array}{l}\text { Rationale for specimen } \\
\text { selection }\end{array}$ \\
\hline $\begin{array}{l}\text { Faboidea crassicutis } \\
\text { Bowerbank }\end{array}$ & V22660 & $\mathrm{Y}$ & Holotype \\
\hline Icacinicarya echinata Chandler & V30182 & Y & Holotype \\
\hline Icacinicarya forbesii Chandler & V30180 & Y & Holotype \\
\hline $\begin{array}{l}\text { Icacinicarya foveolata Reid et } \\
\text { Chandler }\end{array}$ & V22710 & Y & Holotype \\
\hline Icacinicarya glabra Chandler & V30188 & $\mathrm{Y}$ & Holotype \\
\hline $\begin{array}{l}\text { Icacinicarya nodulifera Reid et } \\
\text { Chandler }\end{array}$ & V22706 & $\mathrm{Y}$ & Holotype \\
\hline $\begin{array}{l}\text { Icacinicarya ovalis Reid et } \\
\text { Chandler }\end{array}$ & V22702 & $\mathrm{Y}$ & Holotype \\
\hline $\begin{array}{l}\text { Icacinicarya platycarpa Reid } \\
\text { et Chandler }\end{array}$ & V22686 & Y & Holotype \\
\hline $\begin{array}{l}\text { Icacinicarya reticulata } \\
\text { Chandler }\end{array}$ & V30167 & Y & Holotype \\
\hline $\begin{array}{l}\text { Icacinicarya rotundata } \\
\text { (Bowerbank) Reid et Chandler }\end{array}$ & V22722 & $\mathrm{N}$ & Best surviving specimen \\
\hline $\begin{array}{l}\text { Icacinicarya sp. } 11 \text { (Reid and } \\
\text { Chandler 1933) }\end{array}$ & V22725 & $\mathrm{N} / \mathrm{A}$ & Holotype \\
\hline $\begin{array}{l}\text { Icacinicarya sp. } 12 \text { (Reid and } \\
\text { Chandler 1933) }\end{array}$ & V22726* & $\mathrm{N} / \mathrm{A}$ & Holotype \\
\hline $\begin{array}{l}\text { Iodes corniculata Reid et } \\
\text { Chandler }\end{array}$ & V22579 & $\mathrm{Y}$ & Holotype \\
\hline Iodes davisii Chandler & V30140 & $\mathrm{Y}$ & Holotype \\
\hline $\begin{array}{l}\text { Iodes eocenica Reid et } \\
\text { Chandler }\end{array}$ & V22617 & $\mathrm{N}$ & Best complete specimen \\
\hline Iodes multireticulata Reid et & V22589 & Y & Holotype \\
\hline \multirow[t]{3}{*}{ Chandler } & V22591* & $\mathrm{N}$ & Additional observations \\
\hline & V22595 & $\mathrm{N}$ & Additional observations \\
\hline & V22599* & $\mathrm{N}$ & Additional observations \\
\hline Natsiatum eocenicum Chandler & V45055 & $\mathrm{N}$ & Best surviving specimen \\
\hline $\begin{array}{l}\text { Palaeophytocrene ambigua } \\
\text { Reid et Chandler }\end{array}$ & V22646 & $\mathrm{Y}$ & Holotype \\
\hline Palaeophytocrene foveolata & V22635 & $\mathrm{N}$ & Best complete specimen \\
\hline
\end{tabular}




\begin{tabular}{|c|c|c|c|}
\hline \multicolumn{4}{|l|}{ Reid et Chandler } \\
\hline $\begin{array}{l}\text { Sphaeriodes ventricosa } \\
\text { (Bowerbank) Reid et Chandler }\end{array}$ & V22620 & $\mathrm{N}$ & Best complete specimen \\
\hline Stizocarya communis Reid et & V22647 & Y & Holotype \\
\hline Chandler & V22649 & $\mathrm{N}$ & Additional observations \\
\hline
\end{tabular}

Table 2. Endocarp morphology of modern genera of Icacinaceae. Character data observed from the specimens in Appendix A2 or obtained from the literature (Howard 1942a,b; Sleumer 1971; Peng and Howard 2008).

\begin{tabular}{|c|c|c|c|c|c|c|}
\hline Genus & $\begin{array}{l}\text { Endocarp } \\
\text { surface }\end{array}$ & $\begin{array}{l}\text { Length } \\
\text { (mm) }\end{array}$ & $\begin{array}{l}\text { Width } \\
\text { (mm) }\end{array}$ & $\begin{array}{l}\text { Locule } \\
\text { lining }\end{array}$ & $\begin{array}{l}\text { Vascular } \\
\text { bundle } \\
\text { position }\end{array}$ & $\begin{array}{l}\text { Tubercle } \\
\text { morphology }\end{array}$ \\
\hline $\begin{array}{l}\text { Alsodeiopsis } \\
\text { Oliv. }\end{array}$ & Ridged & $14-27$ & $7-12$ & Smooth & $\begin{array}{l}\text { Outside } \\
\text { endocarp }\end{array}$ & N/A: absent \\
\hline $\begin{array}{l}\text { Casimirella } \\
\text { Hassl. }\end{array}$ & Smooth & $18-75$ & $12-40$ & Pubescent & Tubular canal & N/A: absent \\
\hline $\begin{array}{l}\text { Cassinopsis } \\
\text { Sond. }\end{array}$ & $\begin{array}{l}\text { Rugose, } \\
\text { impressed veins }\end{array}$ & $10-18$ & $7-15$ & Smooth & $\begin{array}{l}\text { Outside } \\
\text { endocarp }\end{array}$ & N/A: absent \\
\hline $\begin{array}{l}\text { Desmostachys } \\
\text { Planch. }\end{array}$ & Ridged & $9-20$ & $7-11$ & Smooth & $\begin{array}{l}\text { Outside } \\
\text { endocarp }\end{array}$ & N/A: absent \\
\hline $\begin{array}{l}\text { Hosiea } \\
\text { Hemsley \& E.H. } \\
\text { Wilson }\end{array}$ & Ridged & $13-18$ & $9-9.5$ & Papillate & $\begin{array}{l}\text { Outside } \\
\text { endocarp }\end{array}$ & N/A: absent \\
\hline $\begin{array}{l}\text { Icacina } \\
\text { A.Juss. }\end{array}$ & $\begin{array}{l}\text { Rugose, } \\
\text { impressed veins }\end{array}$ & $17-30$ & $11-19$ & Smooth & Tubular canal & N/A: absent \\
\hline $\begin{array}{l}\text { Iodes } \\
\text { Blume }\end{array}$ & Ridged & $10-38$ & $7-22$ & Papillate & Endocarp wall & N/A: absent \\
\hline $\begin{array}{l}\text { Lavigera } \\
\text { Pierre }\end{array}$ & $\begin{array}{l}\text { Bumpy-rugose, } \\
\text { impressed veins }\end{array}$ & ca. 50 & ca. 40 & Pubescent & Unknown & N/A: absent \\
\hline $\begin{array}{l}\text { Leretia } \\
\text { Vell. }\end{array}$ & $\begin{array}{l}\text { Smooth, } \\
\text { impressed veins }\end{array}$ & $30-45$ & $20-25$ & Pubescent & Tubular canal & N/A: absent \\
\hline $\begin{array}{l}\text { Mappia } \\
\text { Jacq. }\end{array}$ & $\begin{array}{l}\text { Rugose, } \\
\text { impressed veins }\end{array}$ & $10-25$ & $8-20$ & Smooth & $\begin{array}{l}\text { Outside } \\
\text { endocarp }\end{array}$ & N/A: absent \\
\hline $\begin{array}{l}\text { Mappianthus } \\
\text { Hand.-Mazz. }\end{array}$ & $\begin{array}{l}\text { Rugose, } \\
\text { impressed veins }\end{array}$ & $20-37$ & $10-14$ & Smooth & $\begin{array}{l}\text { Outside } \\
\text { endocarp }\end{array}$ & N/A: absent \\
\hline $\begin{array}{l}\text { Merrilliodendron } \\
\text { Kanehira }\end{array}$ & $\begin{array}{l}\text { Rugose, corky, } \\
\text { lacunose }\end{array}$ & $40-90$ & $20-60$ & Smooth & $\begin{array}{l}\text { Outside } \\
\text { endocarp }\end{array}$ & N/A: absent \\
\hline $\begin{array}{l}\text { Miquelia } \\
\text { Meisn }\end{array}$ & $\begin{array}{l}\text { Ridged and } \\
\text { pitted }\end{array}$ & $8-25$ & $7-18$ & Papillate & $\begin{array}{l}\text { Outside } \\
\text { endocarp }\end{array}$ & $\begin{array}{l}\text { Conical, } \\
\text { shallow }\end{array}$ \\
\hline $\begin{array}{l}\text { Natsiatopsis } \\
\text { Kurz }\end{array}$ & Ridged & $14-17$ & $10-15$ & Smooth & $\begin{array}{l}\text { Outside } \\
\text { endocarp }\end{array}$ & N/A: absent \\
\hline Natsiatum & Ridged & ca. 15 & ca. 10 & Smooth & Outside & N/A: absent \\
\hline
\end{tabular}




\begin{tabular}{|c|c|c|c|c|c|c|}
\hline \multicolumn{5}{|l|}{$\begin{array}{l}\text { Buch.-Ham. ex } \\
\text { Arn. }\end{array}$} & \multicolumn{2}{|l|}{ endocarp } \\
\hline $\begin{array}{l}\text { Arn. } \\
\text { Nothapodytes } \\
\text { Blume }\end{array}$ & $\begin{array}{l}\text { Rugose, } \\
\text { impressed veins }\end{array}$ & $10-20$ & $6-12$ & Smooth & $\begin{array}{l}\text { Outside } \\
\text { endocarp }\end{array}$ & N/A: absent \\
\hline $\begin{array}{l}\text { Phytocrene } \\
\text { Wall. }\end{array}$ & Pitted & $20-60$ & $15-25$ & Smooth & $\begin{array}{l}\text { Outside } \\
\text { endocarp }\end{array}$ & $\begin{array}{l}\text { Shallow } \\
\text { mounds or } \\
\text { absent }\end{array}$ \\
\hline $\begin{array}{l}\text { Pleurisanthes } \\
\text { Baill. }\end{array}$ & $\begin{array}{l}\text { Rugose, } \\
\text { impressed veins }\end{array}$ & ca. 20 & ca. 10 & Smooth & $\begin{array}{l}\text { Outside } \\
\text { endocarp }\end{array}$ & N/A: absent \\
\hline $\begin{array}{l}\text { Pyrenacantha } \\
\text { Wight }\end{array}$ & Pitted & $10-30$ & $8-18$ & Smooth & $\begin{array}{l}\text { Outside } \\
\text { endocarp }\end{array}$ & $\begin{array}{l}\text { Cylindrical to } \\
\text { plate-like, } \\
\text { elongate }\end{array}$ \\
\hline $\begin{array}{l}\text { Rhyticaryum } \\
\text { Becc. }\end{array}$ & Ridged & $15-40$ & $10-30$ & Smooth & $\begin{array}{l}\text { Outside } \\
\text { endocarp }\end{array}$ & N/A: absent \\
\hline $\begin{array}{l}\text { Sarcostigma } \\
\text { Wight \& Arn. }\end{array}$ & $\begin{array}{l}\text { Smooth to } \\
\text { rugose }\end{array}$ & $25-35$ & $15-20$ & Smooth & $\begin{array}{l}\text { Outside } \\
\text { endocarp }\end{array}$ & N/A: absent \\
\hline $\begin{array}{l}\text { Sleumeria } \\
\text { Utteridge, Nagam. } \\
\& \text { Teo }\end{array}$ & $\begin{array}{l}\text { Smooth to } \\
\text { rugose }\end{array}$ & $12-16$ & $8-11$ & Smooth & $\begin{array}{l}\text { Outside } \\
\text { endocarp }\end{array}$ & N/A: absent \\
\hline $\begin{array}{l}\text { Stachyanthus } \\
\text { Engl. }\end{array}$ & Pitted & $11-21$ & $9-14$ & Smooth & $\begin{array}{l}\text { Outside } \\
\text { endocarp }\end{array}$ & Small bumps \\
\hline
\end{tabular}




\section{Figure captions}

Fig. 1. Iodes bilinica (Ettingshausen) comb. nov. (A) Most complete surviving specimen from the London Clay in the NHMUK collections (V45055) in lateral view, image used with permission from pl. 4, fig. 1 in Chandler (1964), with a subapical pore on each endocarp face (arrow). (B-G) Digital isosurfacerenderings of same specimen: (B) lateral view of endocarp, showing pyrite encrustation since image in (A) was taken, as well as the characteristic network of prominent acute ridges with freely ending ridgelets; $(\mathrm{C})$ dorsal view of endocarp, highlighting the prominent keel that bears the primary vascular bundle within the endocarp wall; (D) oblique dorsal and (E) lateral views of same specimen with endocarp rendered transparent to reveal the internal course of the main vascular bundle along the dorsal margin (canal filled with pyrite, indicated with arrows) and the locule cast with distinct depressions enclosed by ridges (areoles) over the lateral faces, reflecting the endocarp surface pattern; (F) apical view of endocarp; (G) apical view of locule cast, superimposed on an $\mu \mathrm{CT}$ transverse section through the fruit revealing relative thickness of the endocarp wall. $(\mathrm{H}-\mathrm{K}) \mu \mathrm{CT}$ sections through the endocarp: $(\mathrm{H})$ longitudinal section approximately in plane of bisymmetry, showing course of main vascular bundle with in the wall (arrows); (I) longitudinal section parallel to that in $\mathrm{H}$, but near the periphery, showing how depressions on the endocarp surface relate to convexities on the inner endocarp surface, leading to similar depressions on the locule cast. (J, K) Transverse sections showing position of vascular bundle (arrows) within wall despite fragmentation of the specimen due to pyrite decay. Scale bar in A (applies also to $\mathrm{B}-\mathrm{E})=1 \mathrm{~cm}$; bars in $\mathrm{F}-\mathrm{K}=5 \mathrm{~mm}$. 
Fig. 2. Iodes corniculata Reid et Chandler emend. (A-J) Holotype (V22579). (A-C) Reflected light images, used with permission from pl. 14, figs. 34-36 in Reid and Chandler (1933), showing show the characteristic subapical horn-like projections on the lateral faces (arrows). (D-F) Isosurface renderies of lateral, dorsal, and ventral views of same specimen with endocarp rendered transparent to reveal internal the course of the main vascular bundle along the dorsal margin and the locule cast with shallow concavities corresponding with the endocarp sculpture with very few freely ending ridgelets. These show the course of the main vascular bundle and the stylar canal entering the endocarp at the confluence of the vascular bundle and subapical horns (arrows). (G-I) $\mu \mathrm{CT}$ transverse sections through the holotype: $(\mathrm{G})$ very near the apex; $(\mathrm{H})$ in upper half; (I) median. (H and I) show the vascular bundle passing through the endocarp wall (arrows) and (I) demonstrates that the inner endocarp surface (against which the locule cast forms) reflects ornamentation of the external endocarp surface. $(\mathrm{J})$ Digital rendering of locule cast and vasculature viewed apically. (K-L) Additional specimens by reflected light; used with permission from from pl. 14, figs. 39-40 in Reid and Chandler (1933): (K) Lateral view of a locule cast (V22583); (L) Lateral view of a specimen with part of endocarp missing (V22582). Scale bar in $\mathrm{L}=1 \mathrm{~cm}$, applies to all images.

Fig. 3. Iodes eocenica Reid et Chandler. (A-E) Digital isosurface renderings of the most complete surviving specimen from the London Clay in the NHMUK collections (V22617, an endocarp): (A, B) opposing lateral views, showing the coarse network of broad rounded ridges; (C, D) opposite sides viewed in dorsiventral orientation; (E) basal view. (F, G) $\mu \mathrm{CT}$ sections through V22617: (F) sagittal longitudinal section (SLS); (G) transverse section. The position of the primary vascular bundle could not be confirmed in 
the $\mu \mathrm{CT}$ images, as shown in $\mathrm{E}$ and $\mathrm{G}$, but this information was reported from other specimens, now deteriorated, assigned to the species by Reid and Chandler (1933). (HK) Other endocarps assigned to Iodes eocenica, images used with permission from pl. 15, figs. 12-15 in Reid and Chandler (1933). (H-J) Original holotype (V22615), now lost: (H) lateral view; (I) apical view; (J) opposite lateral view to $\mathrm{H}$, showing the position of the raphe [r]. (K) Additional endocarp (V22616) in lateral view. Scale bars $=5 \mathrm{~mm}$ in AF (bar in D applies to A-F); $10 \mathrm{~mm}$ in $\mathrm{H}-\mathrm{K}$ (bar in $\mathrm{K}$ applies also to $\mathrm{H}-\mathrm{I}$ ).

Fig. 4. Iodes multireticulata Reid et Chandler from the London Clay Formation. (A-G, IK) Holotype (V22589): (A) endocarp in lateral view, by reflected light, used with permission from pl. 15, fig. 1 in Reid \& Chandler (1933), with numerous (thirty to fifty) concave depressions across the lateral faces; $(\mathrm{B}-\mathrm{G})$ digital renderings of the from $\mu \mathrm{CT}$ scan data; (B) isosurface in lateral view showing outer pyritic encrustation formed since image in A was taken; (C) translucent volume rendering of the endocarp, with locule cast isosurface rendering within, lateral view; (D) lateral view of locule cast showing depressions corresponding to those on the endocarp surface seen in A; (E) basal view of $\mathrm{B}$; (F) apical view of locule cast, superimposed on an $\mu \mathrm{CT}$ transverse section through the endocarp; (G) ventral view of locule cast. (H, L-M) Digital isosurface renderings of V22595, a seed/internal cast of seed with adherent endocarp: (H) lateral view; (L) basal view with outer pyritic encrustation; (M) apical view of locule cast. (I-K) $\mu \mathrm{CT}$ transverse sections through the holotype: (I) median; (J) in upper third; (K) in upper quarter. None of the transverse sections $(\mathrm{I}-\mathrm{K})$ or isosurface renderings $(\mathrm{B}-\mathrm{H}, \mathrm{L}-\mathrm{M})$ shows the position of the primary vascular bundle, perhaps due to abrasion or degradation from pyrite decay. As shown in (F) and (I-K), endocarp wall thickness is missing in key areas where the 
vascular bundle may once have been positioned, so this character cannot be assessed in the current state of preservation. (N-Q) A locule cast with adherant remains of endocarp (V22591): (N, O) isosurface rendering of a locule cast with possible apical remains of the vascular bundle, lateral and ventral views, respectively; (P) sagittal section showing remains of endocarp surrounding the locule cast; (Q) transverse section. Scale bars = 5 $\mathrm{mm}$; bar in A applies to A-G; bar in $\mathrm{H}$ applies also to $\mathrm{L}$ and $\mathrm{M}$; bar in I applies also to $\mathrm{J}$ and $\mathrm{K}$; bar in $\mathrm{N}$ applies also to $\mathrm{O}$; bar in $\mathrm{Q}$ applies also to $\mathrm{P}$.

Fig. 5. Faboidea crassicutis Bowerbank emend. (A-L) Holotype (V22660). (A) Basal view, reflected light used with permission from Reid and Chandler (1933, pl. 16, fig. 3). (B-F) Digital isosurface renderings of endocarp in (B, C) lateral, (D) basal, (E) apical, and $(\mathrm{F})$ dorsal orientations showing the irregular corrugation of the endocarp surface. Damage to the apex of the holotype reveals wall thickness and locule cast. (G-L) $\mu \mathrm{CT}$ sections. (G) Longitudinal section showing locule and bisymmetry. (H, I) Parallel sagittal longitudinal sections through the endocarp. $(\mathrm{H})$ Shows the primary vascular bundle running within the thick endocarp wall from the base of the endocarp towards the apex (arrows). (J-l) Successive coronal longitudinal sections intercepting the main vascular bundle (arrows) at different levels taken through the endocarp. Scale bars $=1 \mathrm{~cm}$; bar in A applies to A-G; bar in $\mathrm{H}$ applies also to $\mathrm{I}-\mathrm{L}$.

Fig. 6. Sphaeriodes ventricosa (Bowerbank) Reid \& Chandler emend. (A-H) Most complete surviving specimen from the London Clay in the NHMUK collections (V22620, an endocarp): (A) lateral view by reflected light, used with permission from Reid and Chandler (1933, pl. 15, fig. 20). (B-G) Digital isosurface renderings: (B) dorsal; 
(C) lateral (cf A); (D) opposite lateral; (E) ventral; and (F) basal views. (G) Apical view of endocarp rendered partially translucent to reveal locule cast inside, superimposed on an $\mu \mathrm{CT}$ transverse section. (A-C) show the coarsely nodular/rugose external appearance of the endocarp. (H) $\mu \mathrm{CT}$ median transverse section through the endocarp. (I-M) Additional endocarp of S. ventricosa (V64890): (I) apical, (J) ventral, and (K) lateral views by reflected light. (L) Transverse section by reflected light, showing the vascular bundle embedded within the endocarp wall (a. (M) Enlargement of section in L, reflected light. Scale bars $=1 \mathrm{~cm}$ in $\mathrm{A}$ (applies also to $\mathrm{B}-\mathrm{H}$ ) and $\mathrm{K}$ (applies also to $\mathrm{I}, \mathrm{J}$ ), $5 \mathrm{~mm}$ in $\mathrm{L}$, and $1 \mathrm{~mm}$ in $\mathrm{M}$.

Fig. 7. Palaeophytocrene foveolata Reid et Chandler emend. (A-J) The most complete surviving specimen from the London Clay in NHMUK collections (V22635). (A) Lateral view by reflected light, image used with permission from from Reid and Chandler (1933, pl. 15, fig. 27). (B-G) Digital isosurface renderings of the locule cast: (B) same view as in A, but with basal extremity no longer visible, showing the numerous, small pits on the locule cast surface, arranged in irregular longitudinal rows, likely corresponding to a similar arrangement of pits on the endocarp surface. $(C, D)$ dorsal and ventral views; $(E)$ apical view; (F) basal view; (G) oblique apical view showing possible apical aperture (arrow). (H) Dorsal or ventral view by reflected light, image used with permission from Reid and Chandler (1933), pl. 15, fig. 28 (cf fig. C). (I-J) $\mu$ CT digital sections showing the lack of any adherent surficial endocarp, but remnant intrusion of endocarp into the locule (arrows): (I) coronal longitudinal section; (J) transverse section. Scale bars $1 \mathrm{~cm}$; bar in A applies also to B-I. 
Fig. 8. Palaeophytocrene ambigua Reid et Chandler emend. and Icacinicarya jenkinsi Reid et Chandler. (A-H) Holotype of P. ambibua (V22646). (A) lateral view, reflected light image used with permission from pl. 15, fig. 34 in Reid and Chandler (1933). (B-E) Digital isosurface renderings, showing the locule cast with adhering endocarp in places: (B) lateral view, as in A, showing the irregular longitudinal rows of pits across the locule cast; (C, D) side/marginal views; (E) apical view. (F-H) $\mu \mathrm{CT}$ transverse sections showing patches of endocarp penetrated by pits, forming parallel-sided canals (arrows) within tubercles projecting into the locule cast; also note remnant seed coat (s) within the locule. (I) Holotype of I. jenkinsii (V22720): a locule cast with features resembling extant Miquelia, viewed by reflected light, image used with permission from Reid and Chandler (1933, pl. 16, fig. 36). Scale bars $1 \mathrm{~cm}$ in A (applies also to B-F), and I; $5 \mathrm{~mm}$ in G (applies also to $\mathrm{H}$ ).

Fig. 9. Perforatocarpum echinatum (Chandler), gen. et comb. nov. (A-H) Holotype (V30182). (A) Reflected light image used with permission from pl. 22, fig. 42 in Chandler (1961). (B-F) Digital isosurface renderings: (B) lateral; (C) opposite lateral; (D) ventral; (E) dorsal; and (F) apical views. (F) Shows remnants of the primary vascular bundle, with two subapical channels flanking the stylar canal. Vascular bundle indicated with arrows in B, C, and F; pair of channel-like structures indicated with arrows in F. Pyrite infillings of the original endocarp wall (now eroded away) projecting from the locule cast visible in $\mathrm{B}-\mathrm{F}$. $(\mathrm{G}, \mathrm{H}) \mu \mathrm{CT}$ transverse sections: $(\mathrm{H})$ detail showing pyrite infillings of the original endocarp pits, now projecting from the abraded endocarp wall. Scale bars = $5 \mathrm{~mm}$; bar in A applies also to B-E. 
Fig. 10. Stizocarya communis Reid et Chandler emend. (A-D) Holotype (V22647). (A) Reflected light image used with permission from Reid and Chandler (1933, pl.16, fig. 35). (B, C) Digital isosurface renderings: (B) same view as A; (C) lateral view showing partially removed endocarp wall with locule cast protruding to the right; (D) longitudinal section showing thickness of wall with anticlinal channels visible in places (arrows). (EH) Locule cast (V22649) with protrusions representing the resistant pyrite infillings of channels in the original endocarp wall. (E) Apical view, reflected light image used with permission from Reid and Chandler (1933, pl. 15, fig. 37). (F-H) Digital isosurface renderings: (F) apical view showing the two channels/ducts (arrows) emerging from the primary vascular bundles as in E; (G) dorsal view showing vascular bundle (arrow), $(\mathrm{H})$ ventral view. (I-K) Additional specimen (V22658) by reflected light: (I) dorsal or ventral; (J) opposite side; (K) lateral view. (L) Digital transverse section of the specimen in E-H. (M) Physical transverse section of specimen in I-K, showing anticlinal channels in endocarp wall, reflected light. (N) Digital transverse section of holotype (same as AD), with detail of anticlinal channels in the endocarp wall. (O) Detail of physical section enlarged from M. Scale bars $=1 \mathrm{~cm}$ in A (applies also to B-L); $5 \mathrm{~mm}$ in $\mathrm{M}$ and $\mathrm{N} ; 1 \mathrm{~mm}$ in $\mathrm{O}$.

Fig. 11. Icacinicarya davisii (Chandler), comb. nov. (A-L) Holotype (V30140). (A-E) Digital isosurface renderings of the endocarp, showing a network of sunken fibers across its surface: (A) lateral; (B) opposite lateral; (C) ventral; (D) dorsal; and (E) apical views. (F-G) Endocarp images used with permission from pl. 22, figs. 7-8 in Chandler (1961):

(F) lateral view, as in A; (G) opposite view, as in B. (H) $\mu \mathrm{CT}$ sagittal longitudinal section through the holotype, showing the small canal flanking the style near the apex and 
connecting to the primary vascular bundle, which enters the locule subapically. (I) Translucent volume rendering of the holotype. (J-L) $\mu \mathrm{CT}$ transverse sections (TS) through the holotype, which show the primary vascular bundle travelling outside the endocarp wall for most of its length: (J) TS one-third up the fruit; (K) TS two-thirds up the fruit; (L) TS near the fruit apex. Scale bars $=5 \mathrm{~mm}$ in E (also applies to A-I) and L (also applies to $\mathrm{J}, \mathrm{K}$ ).

Fig. 12. Icacinicarya forbesii Chandler. (A) Holotype endocarp (V30180) in lateral view, image used with permission from pl. 22, fig. 35 in Chandler (1961). (B) Digital isosurface rendering of the holotype endocarp, opposite lateral view to A; A and B show the nodular-like ornamentation over the lateral faces of the endocarp. (C-E) $\mu \mathrm{CT}$ transverse sections through the holotype, showing the thick endocarp wall with ridges, indicative of Icacinaceae: (C) median; (D) in upper third; (E) apical. (F) $\mu$ CT coronal longitudinal section through the holotype. $(\mathrm{C}-\mathrm{F})$ reveal that the nodular ornamentation in $\mathrm{A}$ and $\mathrm{B}$ is due to the preservation of the specimen. The spaces between ridges on the endocarp were filled by pyrite and some of the ridges have been worn away leaving protruding pyrite nodules. Scale bars $=1 \mathrm{~cm}$ in $\mathrm{A}$ (also applies to $\mathrm{B}-\mathrm{E}$ ) and $5 \mathrm{~mm}$ in $\mathrm{F}$.

Fig. 13. Icacinicarya glabra Chandler. (A-D, G) Digital isosurface renderings of the holotype (V30188): (A) lateral, (B) opposite lateral, (C) ventral, (D) dorsal, and (G) basal views of endocarp. (A-D) show the relatively smooth surface, except for areas of pyrite encrustation. (E-F) $\mu \mathrm{CT}$ sagittal longitudinal sections through the holotype: $(\mathrm{E})$ away from the plane of bisymmetry; $(\mathrm{F})$ median. $(\mathrm{H}-\mathrm{J}) \mu \mathrm{CT}$ transverse sections taken at different positions through the holotype: $(\mathrm{H})$ median; (I) in upper third; (J) apical. (E-F) 
and $(\mathrm{H}-\mathrm{J})$ show that the endocarp wall is relatively thin and in areas covered by separate pyrite encrustation. Scale bar $=1 \mathrm{~cm}$ in $\mathrm{A}$ (also applies to $\mathrm{B}-\mathrm{G}$ ), $5 \mathrm{~mm}$ in $\mathrm{H}$ (also applies to I, J).

Fig. 14. Icacinicarya nodulifera Reid et Chandler. (A-D) Digital isosurface renderings of the holotype (V22706): (A) side, (B) opposite side, (C) lateral, and (D) opposite lateral views of endocarp; (D) suggests the endocarp surface was smooth, but this may be a product of abrasion or degradation due to pyrite decay, because the locule cast is coarsely ridged and faceted, as shown in $\mathrm{C} .(\mathrm{E}-\mathrm{F}) \mu \mathrm{CT}$ sagittal longitudinal sections through the holotype: (E) median; (F) slightly away from line of bisymmetry, towards the lateral face with endocarp preserved. $(\mathrm{G}) \mu \mathrm{CT}$ median transverse section through the holotype. Scale bar $=1 \mathrm{~cm}$ in $\mathrm{D}$ (also applies to A-C), F (also applies to E), G.

Fig. 15. Icacinicarya ovalis Reid et Chandler. (A-E) Digital renderings of the holotype endocarp (V22702), showing the low, rounded ridges and small concavities across the lateral faces (A-D), as well as the thick encircling ridge $(\mathrm{B}, \mathrm{C}, \mathrm{E})$ around the endocarp in the plane of symmetry: (A) lateral, (B) opposite lateral, (C) side, (D) opposite side, and (E) Basal views. (F-I) $\mu \mathrm{CT}$ transverse sections (TS) through the holotype: (F) median; (G) basal; (H-I) near the apex. (F-I) show the thick endocarp wall with no sign of the primary vascular bundle running through it. Instead the vascular bundle is inferred to have run outside the wall along one margin. Scale bar $=1 \mathrm{~cm}$ in $\mathrm{D}$ (applies to A-E, G), 5 $\mathrm{mm}$ in $\mathrm{F}$ (also applies to $\mathrm{H}, \mathrm{I})$. 
Fig. 16. Icacinicarya platycarpa Reid et Chandler. (A) Holotype locule cast (V22686) in lateral view, image used with permission from pl. 16, fig. 11 in Reid and Chandler (1933). (B-G) Digital isosurface renderings of the holotype: (B) lateral (C) opposite lateral, (D) side, (E) Opposite side, and (F) apical views; (G) apical view, superimposed on an $\mu \mathrm{CT}$ transverse section. (A-C) show the reticulum of ridges across the lateral faces of the locule cast and suggest the original endocarp was also reticulately ridged. (H-I) Transverse sections taken at different positions. Scale bar $=1 \mathrm{~cm}$ in A (also applies to BI).

Fig. 17. Icacinicarya reticulata Chandler. (A-D) Digital isosurface renderings of the holotype endocarp (V30167): (A) ventral, (B) dorsal; (C) lateral, and (D) opposite lateral views, showing the network of thick fibers/vasculature partially embedded in endocarp wall. (E-H) $\mu \mathrm{CT}$ transverse sections through the holotype: (E) median; $(\mathrm{F})$ in lower third; (G) taken just above the equatorial level; (H) taken just below the equatorial level. Vascular bundle indicated with arrows in $\mathrm{F}$ and $\mathrm{H}$. Scale bar $=5 \mathrm{~mm}$ in $\mathrm{E}$ (also applies to A-D, F-H).

Fig. 18. "Icacinicarya” foveolata Reid et Chandler (incertae sedis). (A-B) Holotype endocarp (V22710), images used with permission from pl. 16, figs. 27-28 in Reid and Chandler (1933): (A) lateral and (B) side views, showing the smooth and finely tessellated endocarp surface-features uncommon in species of Icacinaceae. (C-F) Digital isosurface renderings of the holotype endocarp: (C) lateral view, opposite to A; (D) side view, as in B; (E) lateral view, as in A; and (F) side view, opposite to B. $(\mathrm{G}-\mathrm{H})$ $\mu \mathrm{CT}$ transverse sections through the holotype: $(\mathrm{G})$ median; $(\mathrm{H})$ in lower third. $\mathrm{D}$ and $\mathrm{G}$ 
also show the notably thick endocarp wall—another feature uncommon in Icacinaceae. Scale bar $=5 \mathrm{~mm}$ in $\mathrm{A}$ (also applies to $\mathrm{B}-\mathrm{H})$.

Fig. 19. "Icacinicarya" sp. $11(\mathrm{~A}-\mathrm{G})$ and "Icacinicarya" rotundata (Bowerbank) Reid et Chandler (incertae sedis) (H-J). (A) Reflected light image, used with permission, of complete specimen (V22725) from Reid and Chandler (1933, pl. 16, fig. 39). (B-D) Digital isosurface renderings of the larger fragment from A: (B) lateral, (C) opposite lateral, and (D) apical views. (E-G) $\mu \mathrm{CT}$ longitudinal sections through V22725: (E, F) sagittal sections; $(\mathrm{G})$ median transverse section. Scale bars $=1 \mathrm{~cm}$ in A and D (applies also to $\mathrm{B}, \mathrm{C}) ; 5 \mathrm{~mm}$ in $\mathrm{E}-\mathrm{G}$. (H) Digital isosurface rendering of the most complete surviving specimen (V22722, a locule cast) from the London Clay in the NHMUK collections, in lateral view. (I) Translucent volume rendering of V22722. H and I show the globular shape of this specimen, but the locule cast is abraded so may not represent its true original shape or the shape of the endocarp. $(\mathrm{J}) \mu \mathrm{CT}$ median transverse section through V22722, showing the lack of endocarp preservation and lack of detail concerning character information, such as the position of the vascular bundle. Scale bars $=5 \mathrm{~mm}$ in A, D (also applies to B, C), E, F, G, and H (also applies to I, J). 


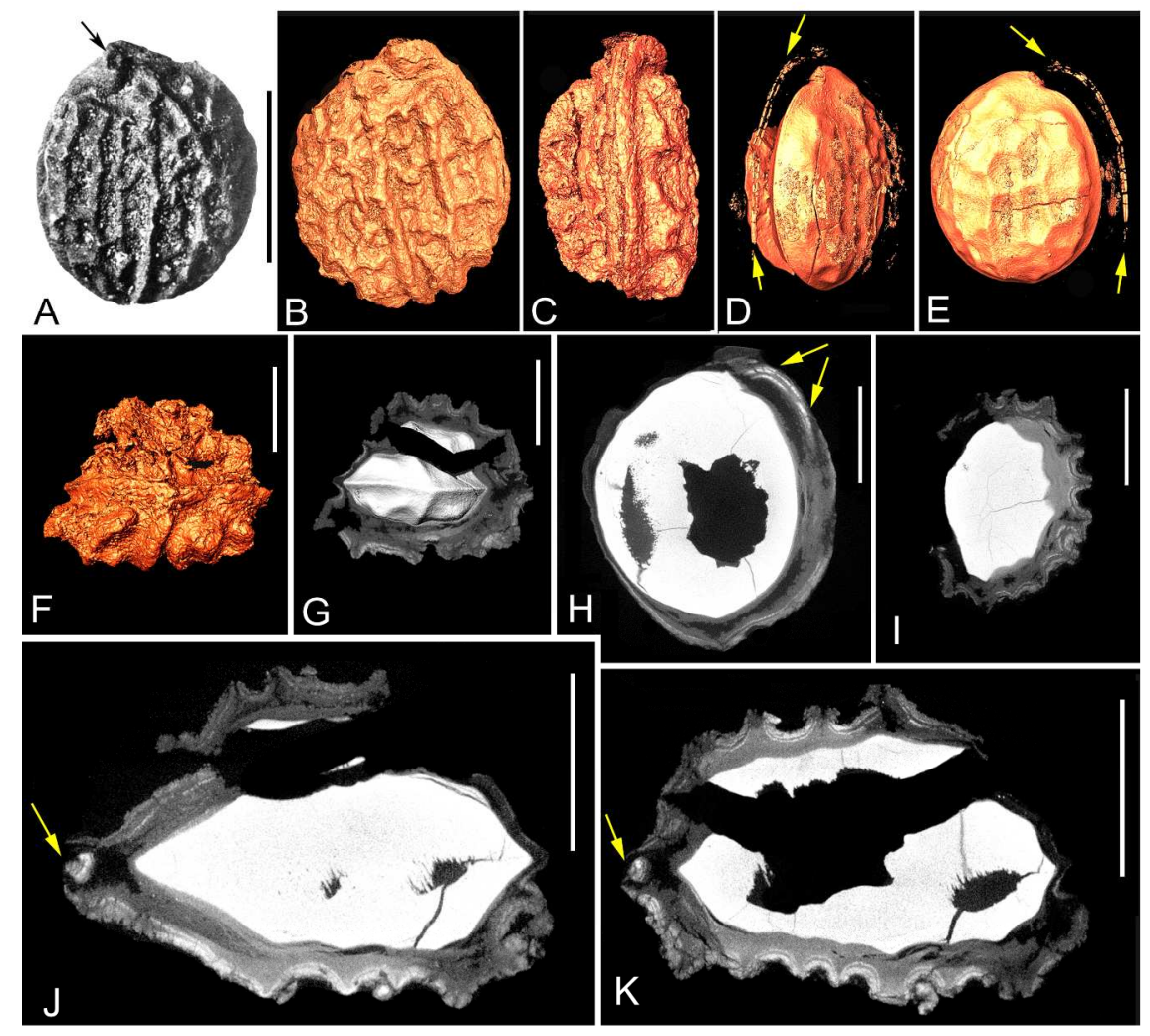

$254 \times 353 \mathrm{~mm}(300 \times 300 \mathrm{DPI})$ 


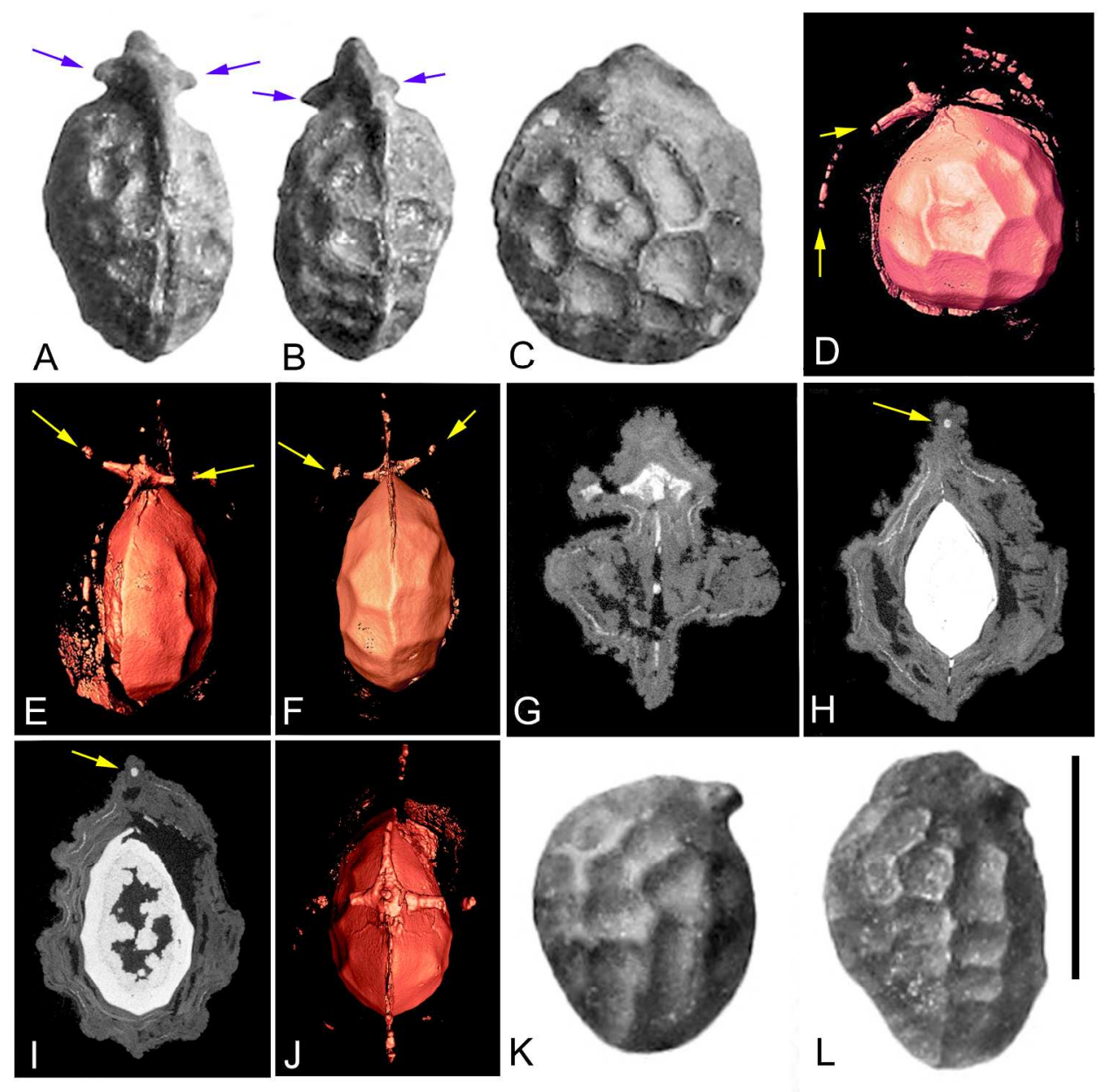

$228 \times 285 \mathrm{~mm}(300 \times 300 \mathrm{DPI})$ 

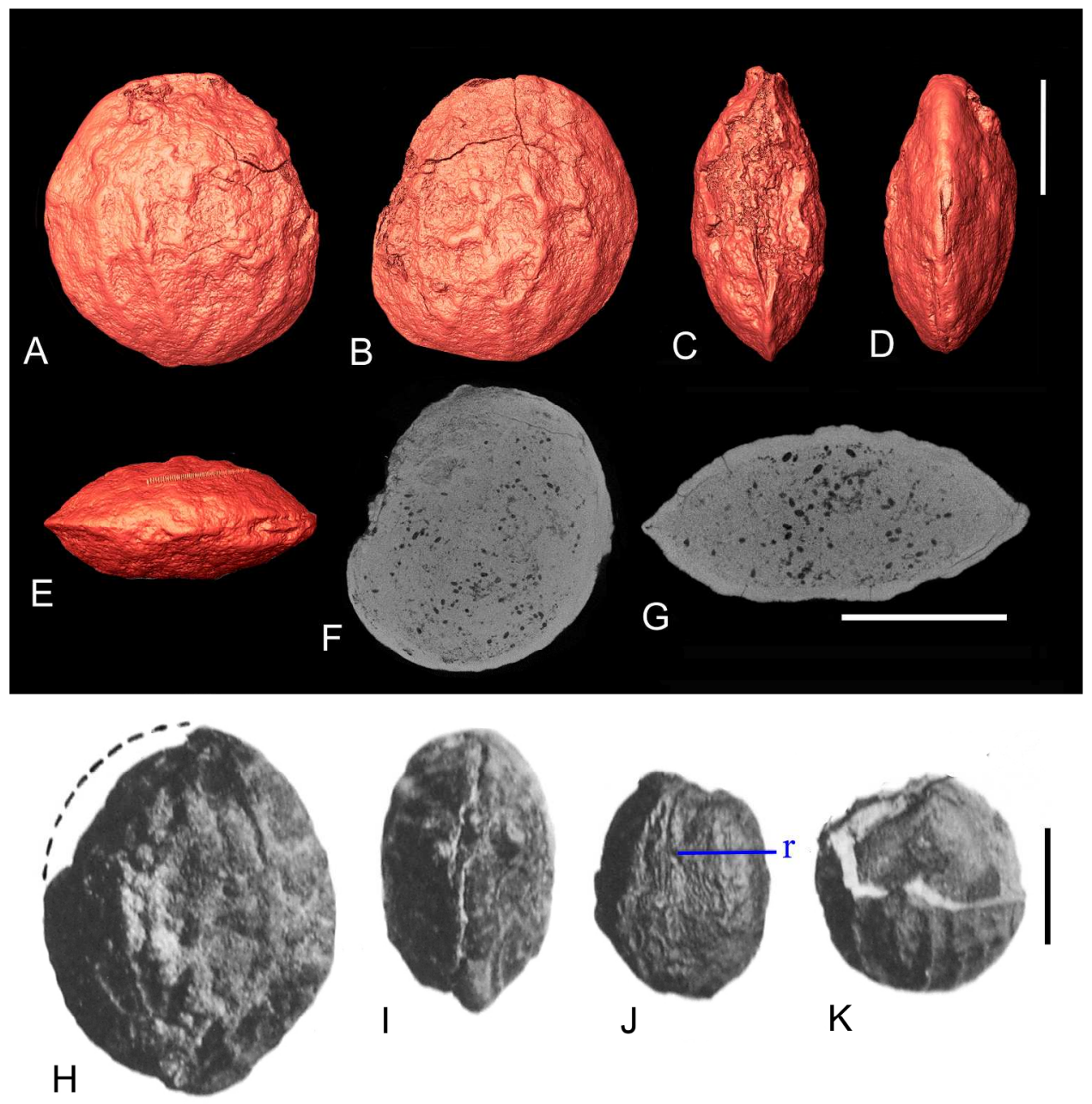

$228 \times 285 \mathrm{~mm}(300 \times 300$ DPI $)$ 


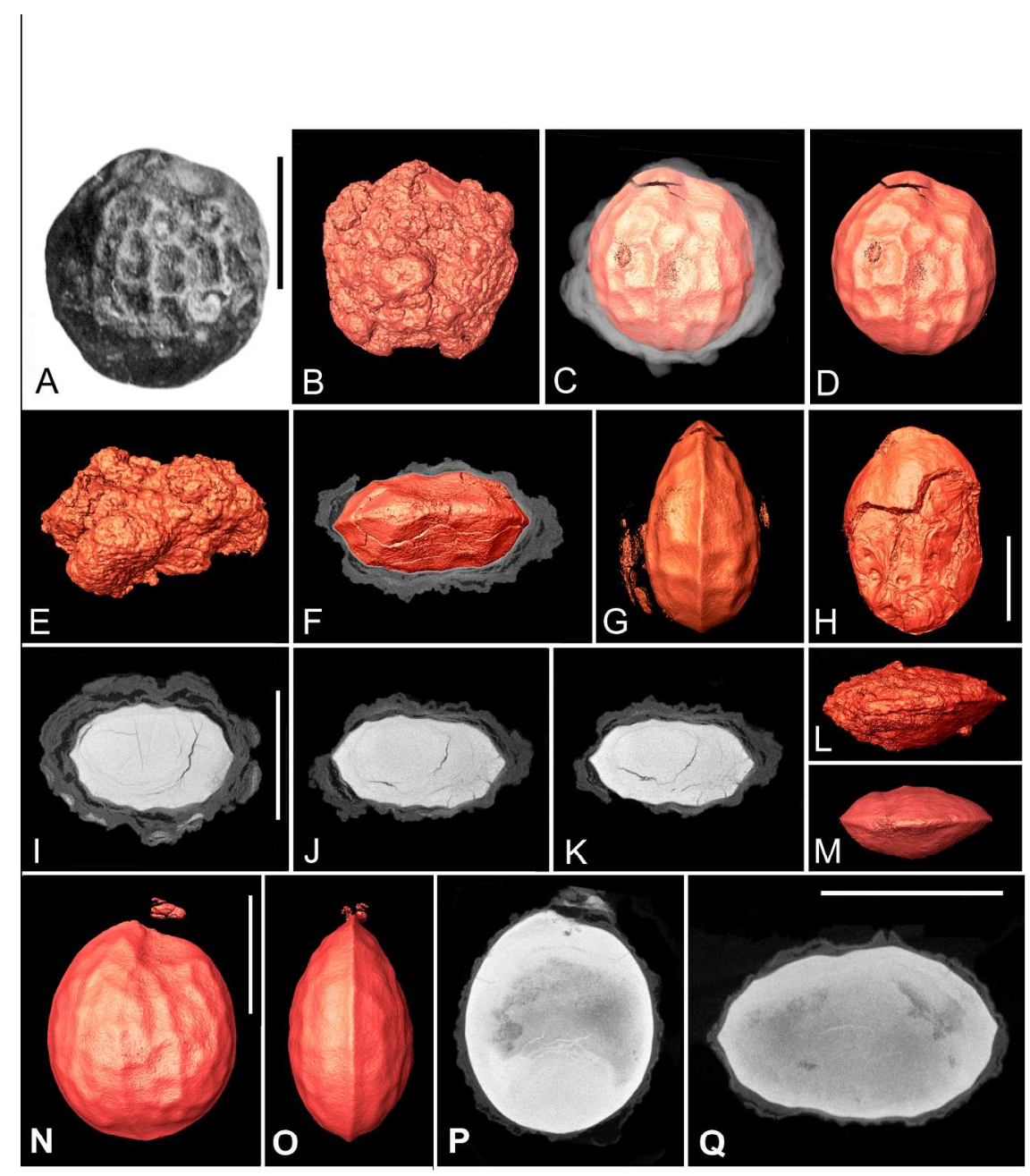

$254 \times 352 \mathrm{~mm}(300 \times 300 \mathrm{DPI})$ 


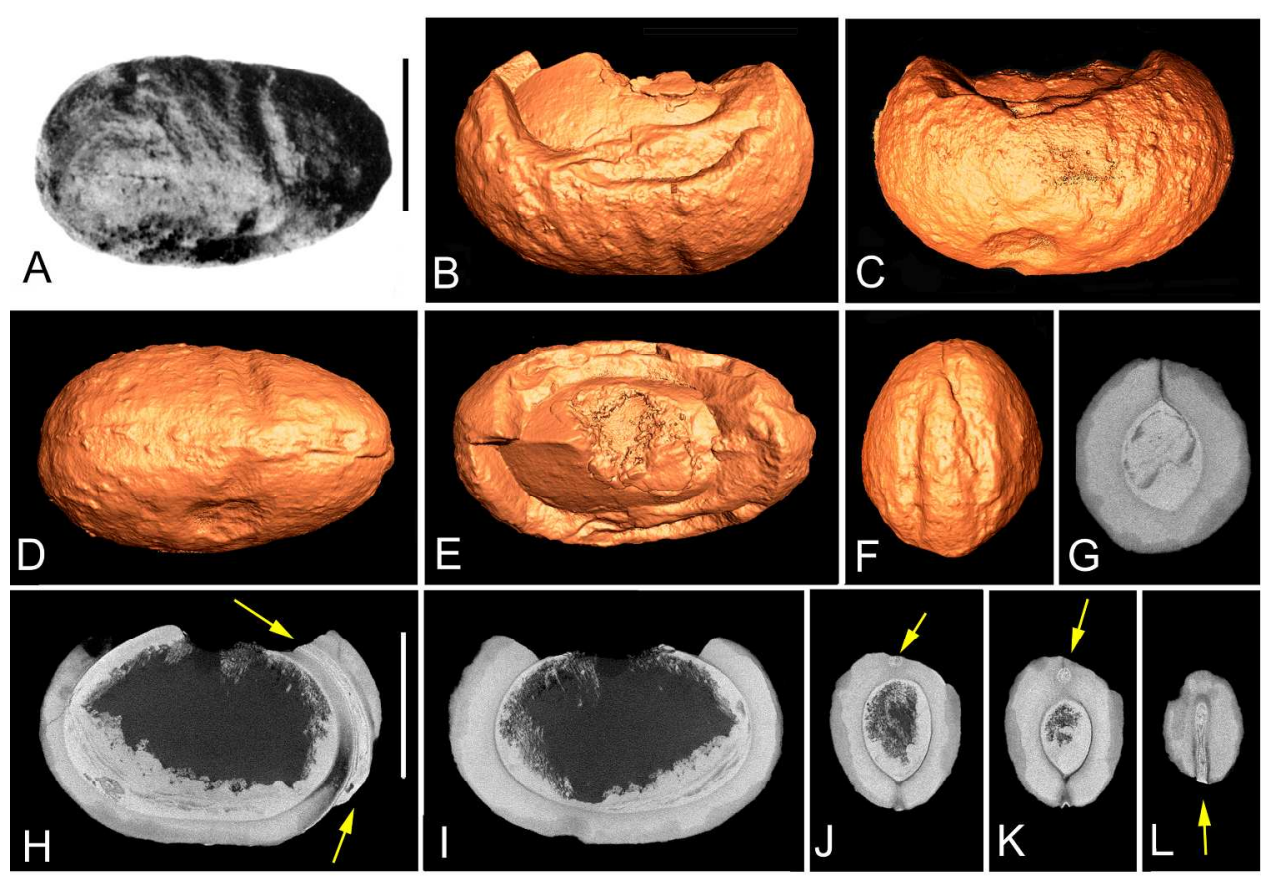

$228 \times 285 \mathrm{~mm}(300 \times 300 \mathrm{DPI})$ 


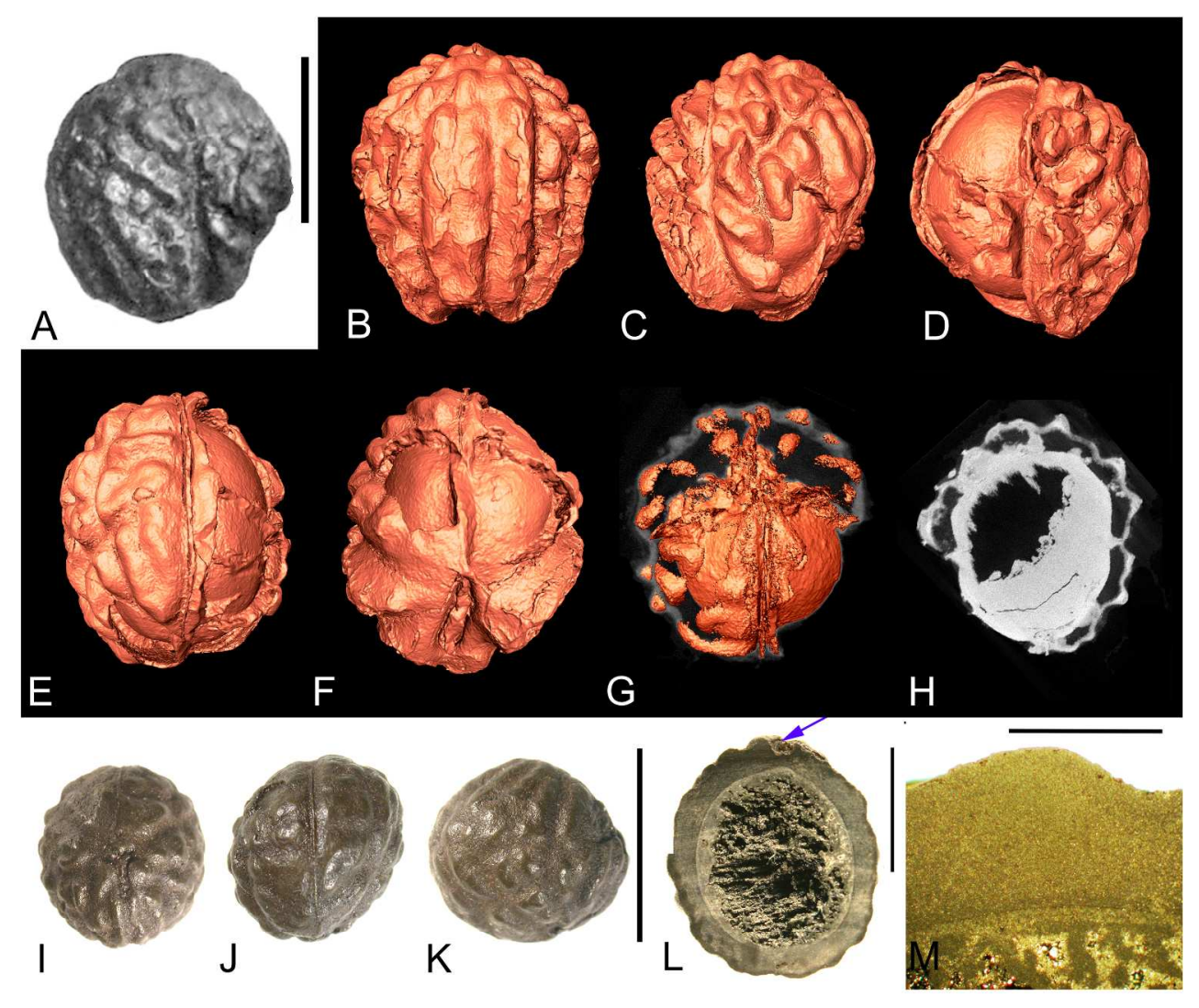

$228 \times 281 \mathrm{~mm}(300 \times 300 \mathrm{DPI})$ 


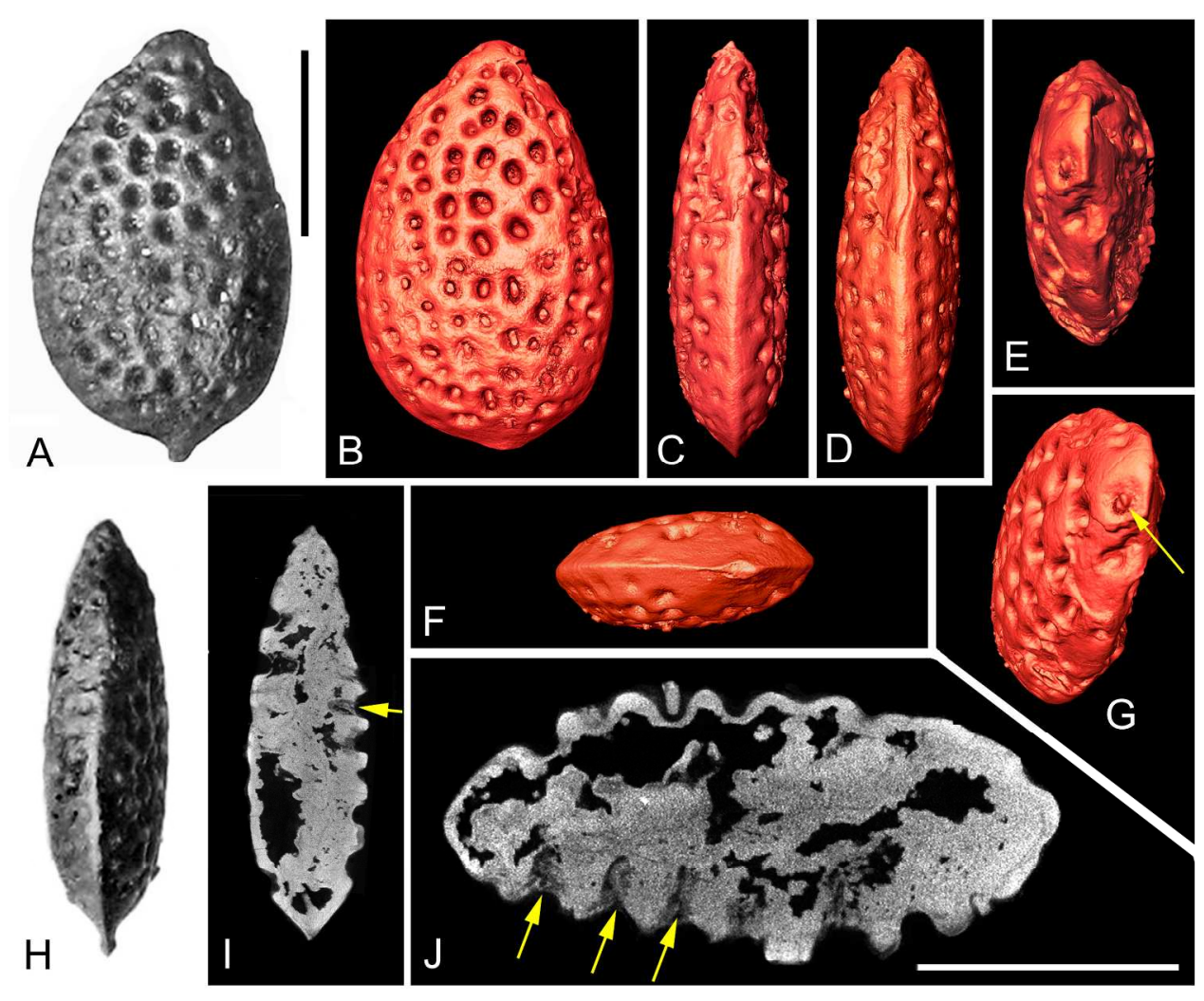

$228 \times 285 \mathrm{~mm}(300 \times 300$ DPI $)$ 


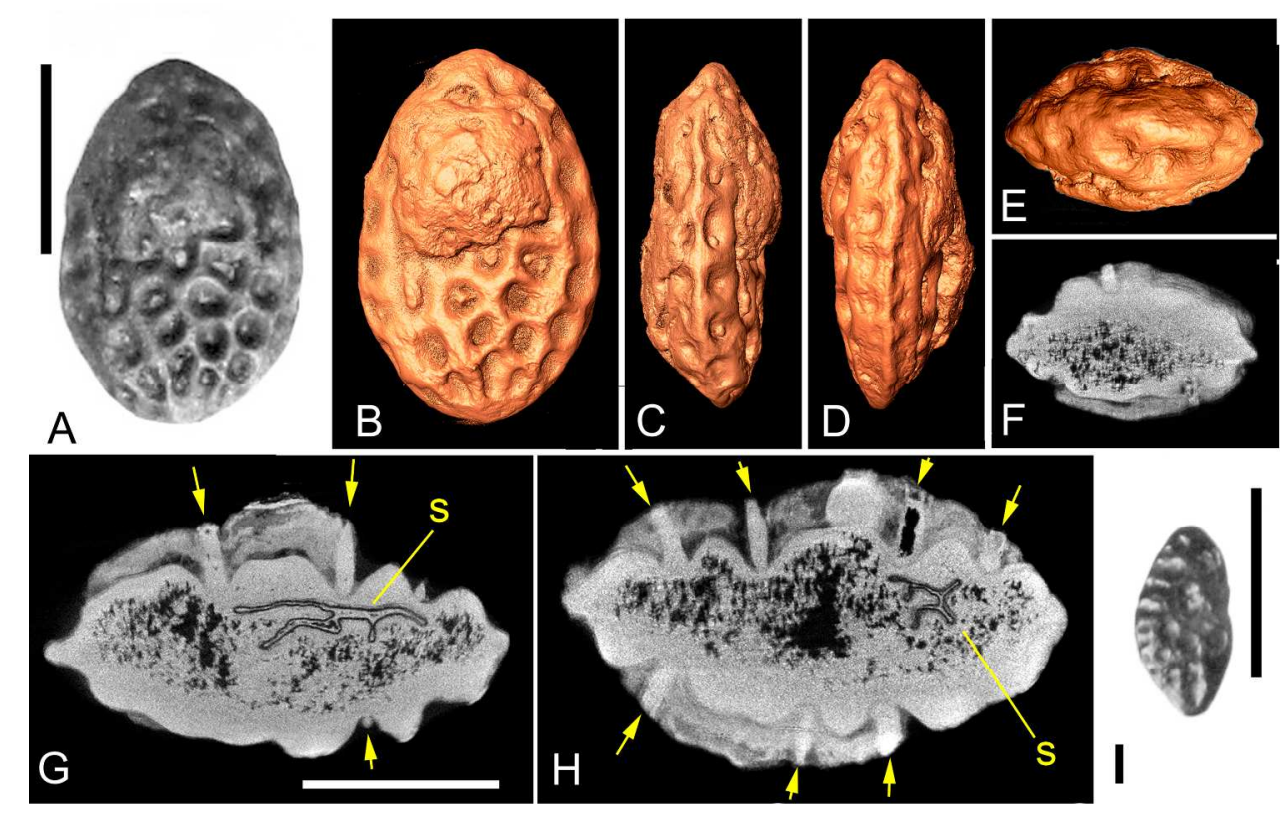

$228 \times 285 \mathrm{~mm}(300 \times 300 \mathrm{DPI})$ 


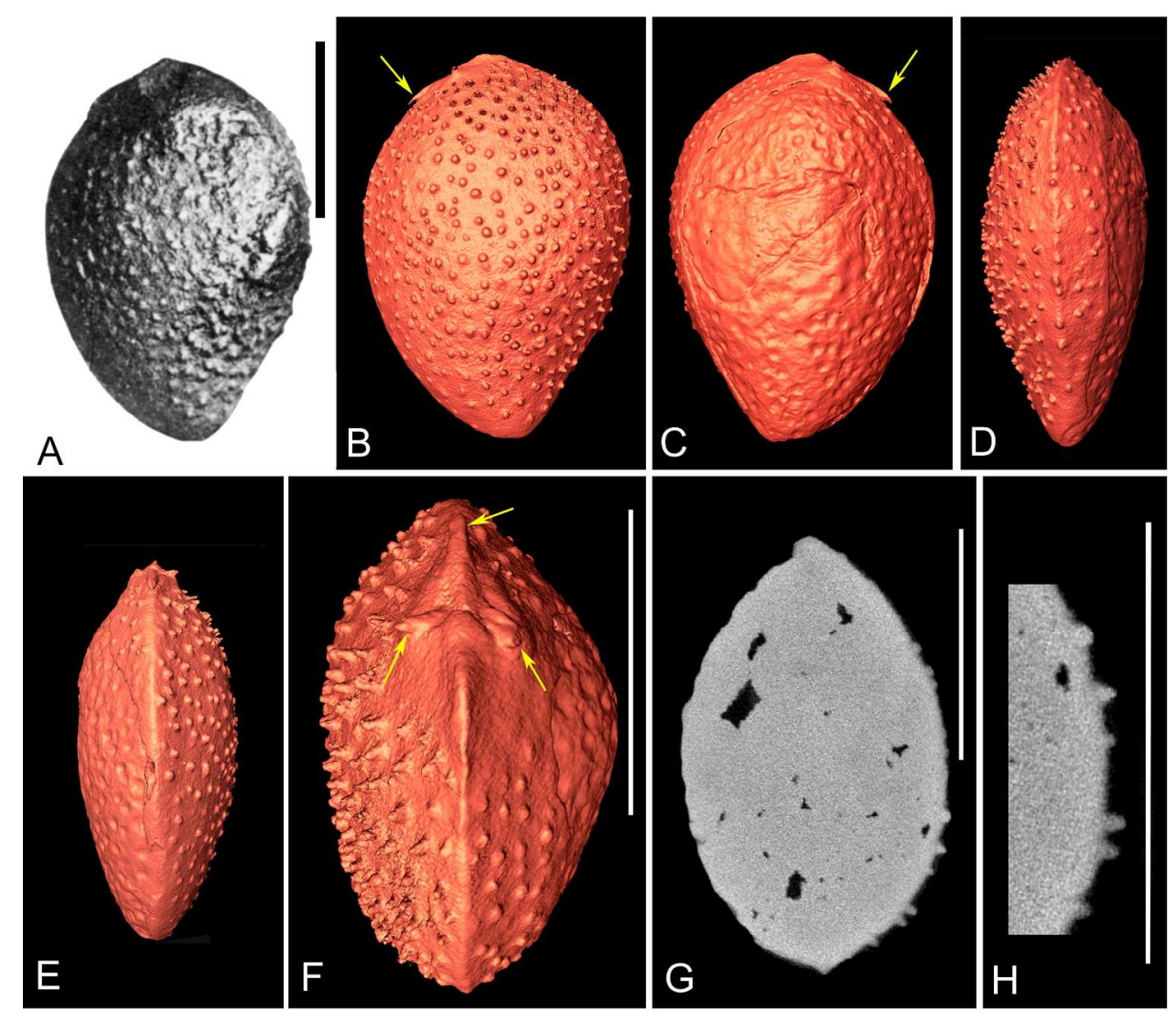

$228 \times 285 \mathrm{~mm}(300 \times 300 \mathrm{DPI})$ 


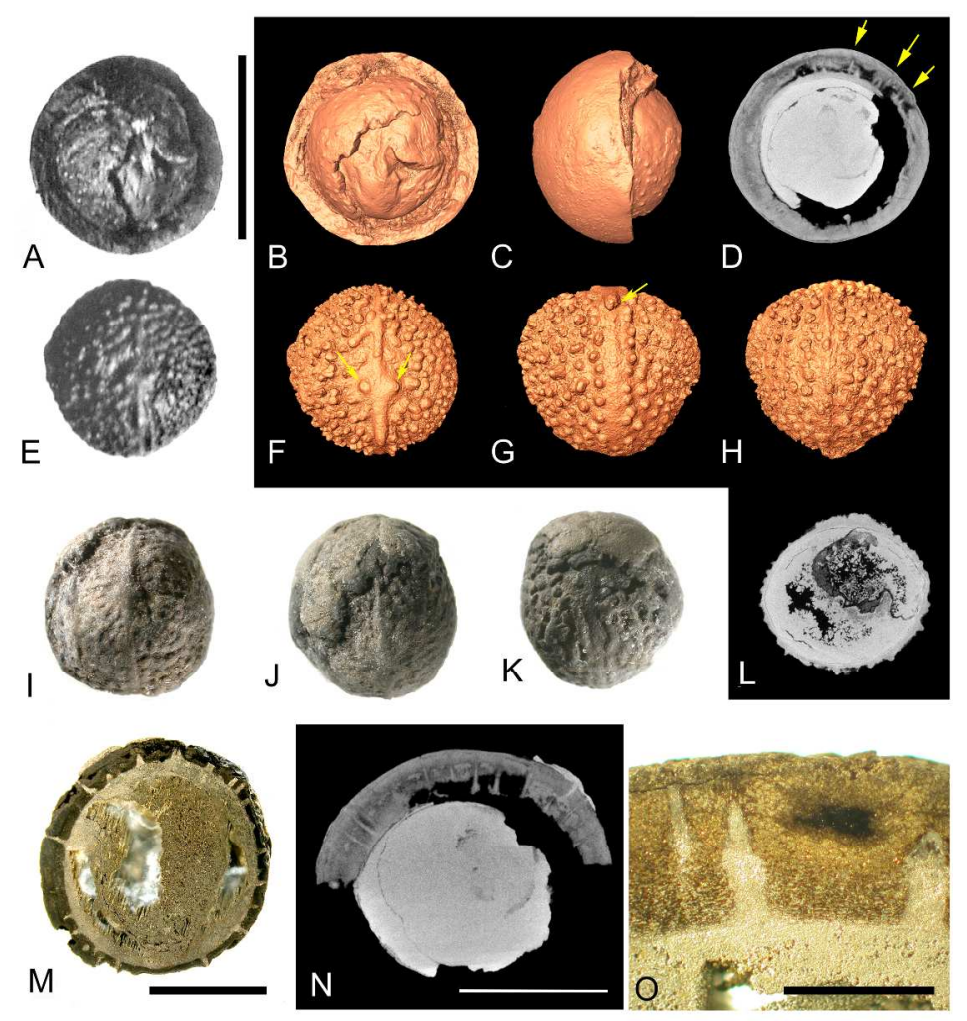

$304 \times 508 \mathrm{~mm}(300 \times 300$ DPI $)$ 

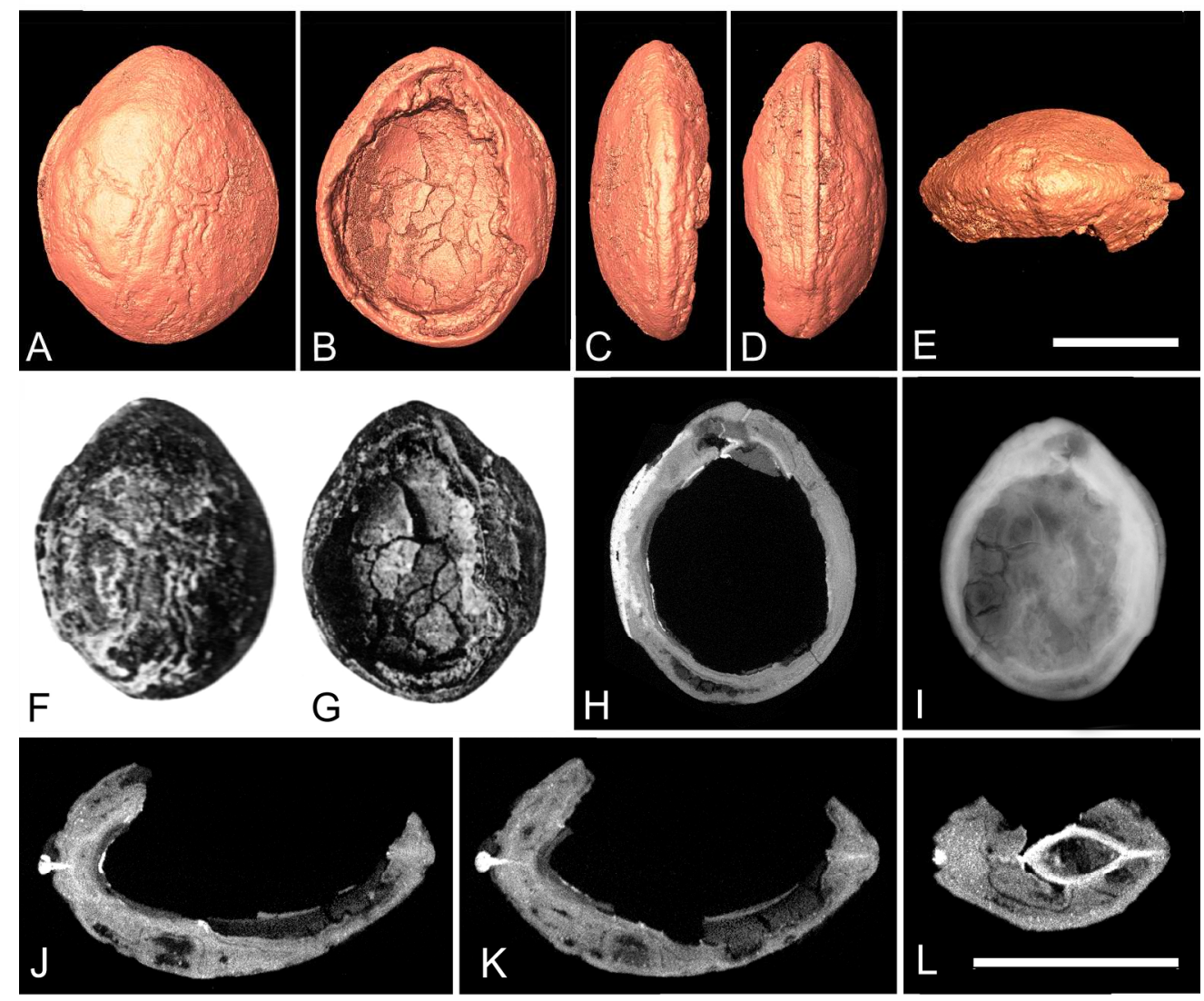

$219 \times 263 \mathrm{~mm}(300 \times 300 \mathrm{DPI})$ 


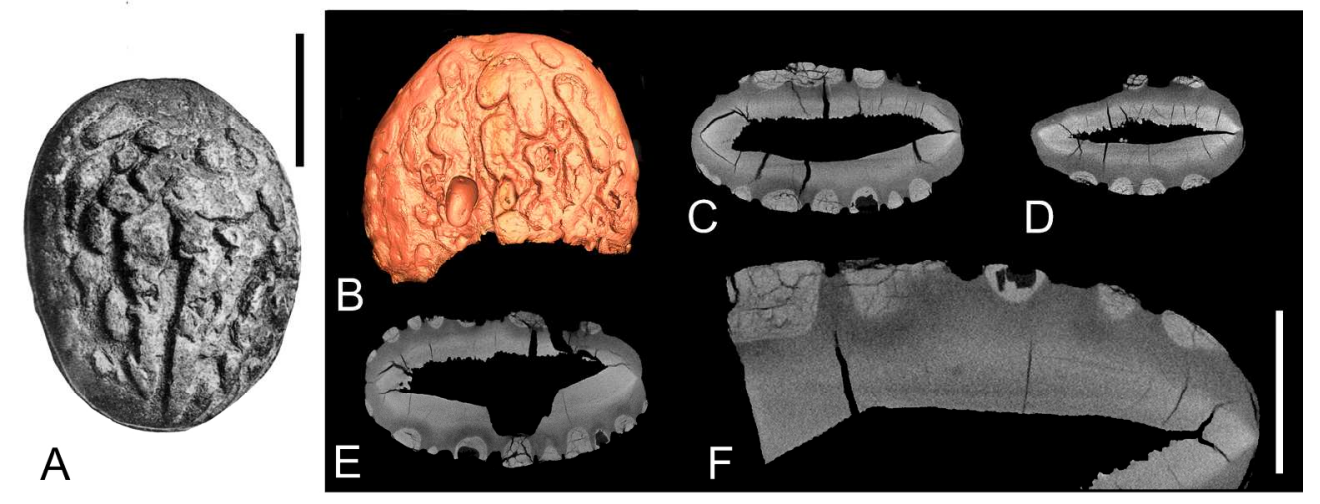

$204 \times 228 \mathrm{~mm}(300 \times 300$ DPI $)$ 


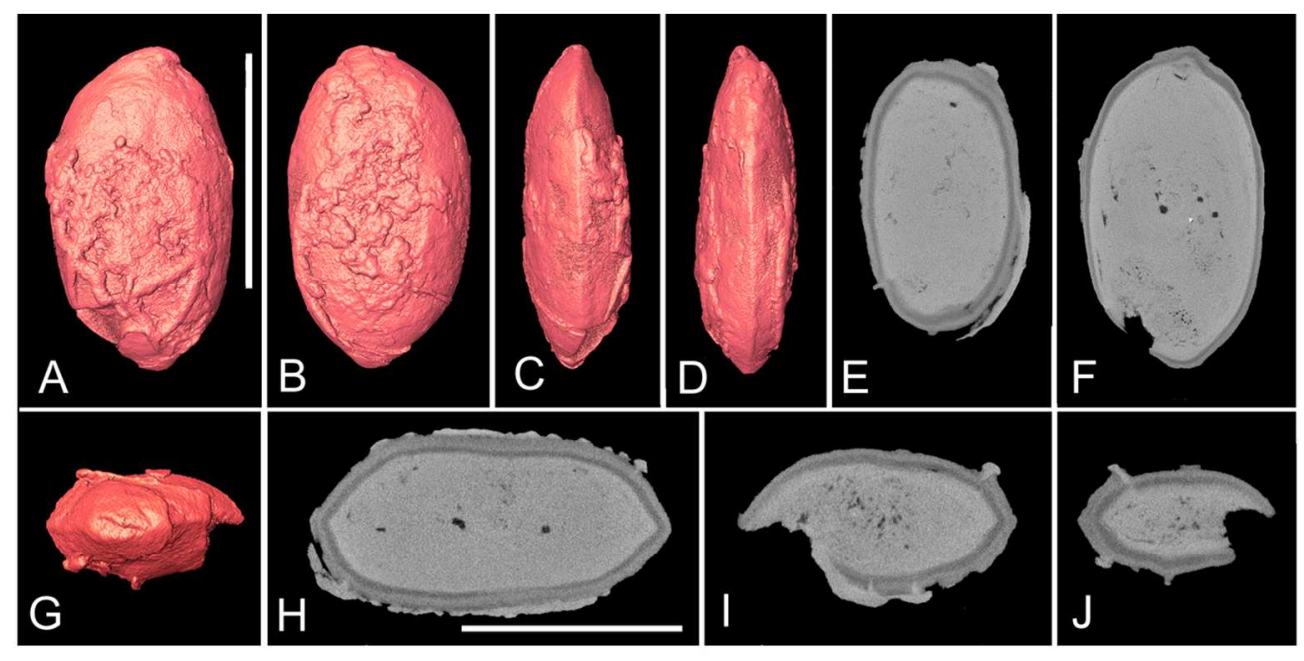

$113 \times 70 \mathrm{~mm}(300 \times 300 \mathrm{DPI})$ 


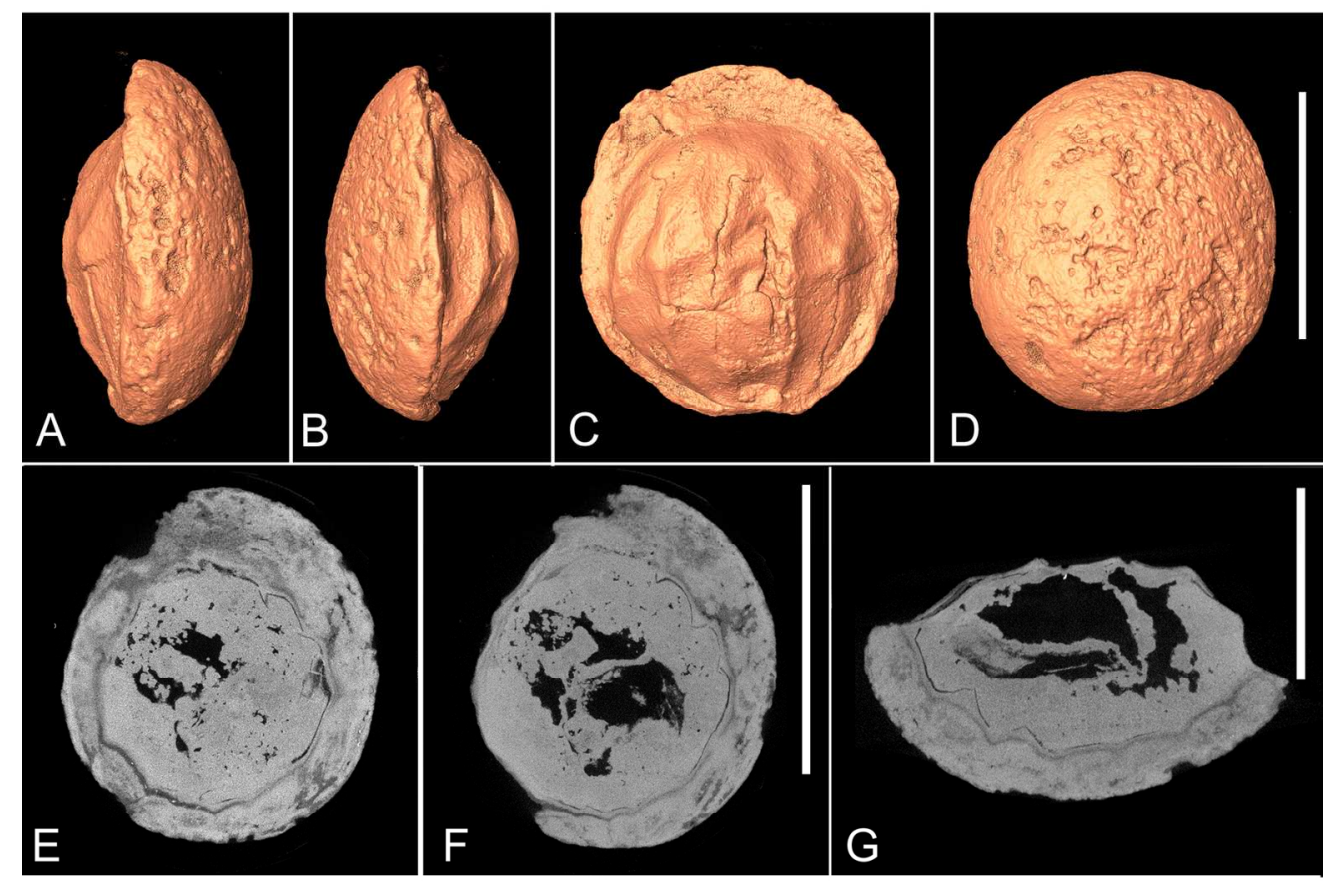

$151 \times 124 \mathrm{~mm}(300 \times 300$ DPI $)$ 


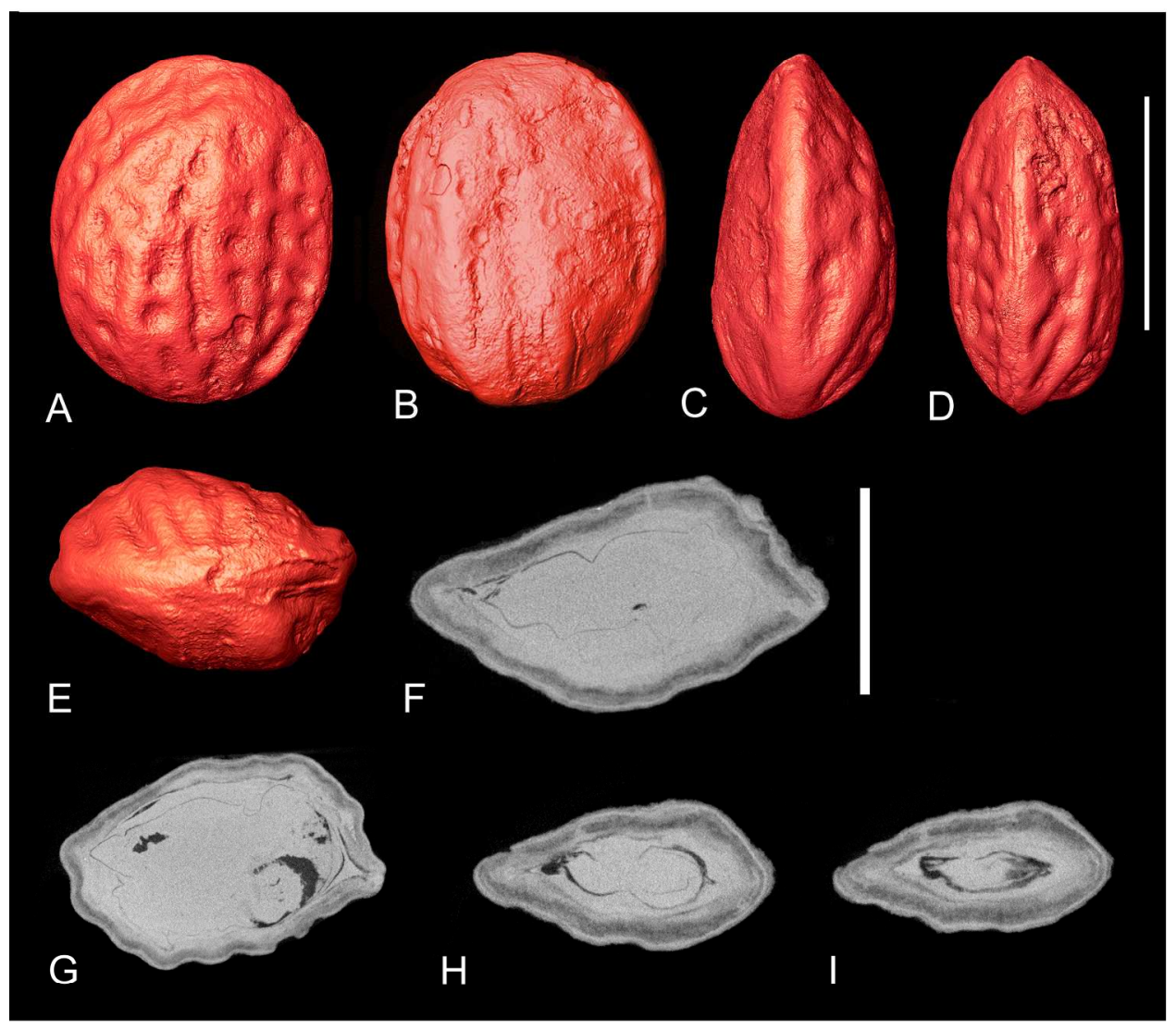

$228 \times 285 \mathrm{~mm}(300 \times 300 \mathrm{DPI})$ 


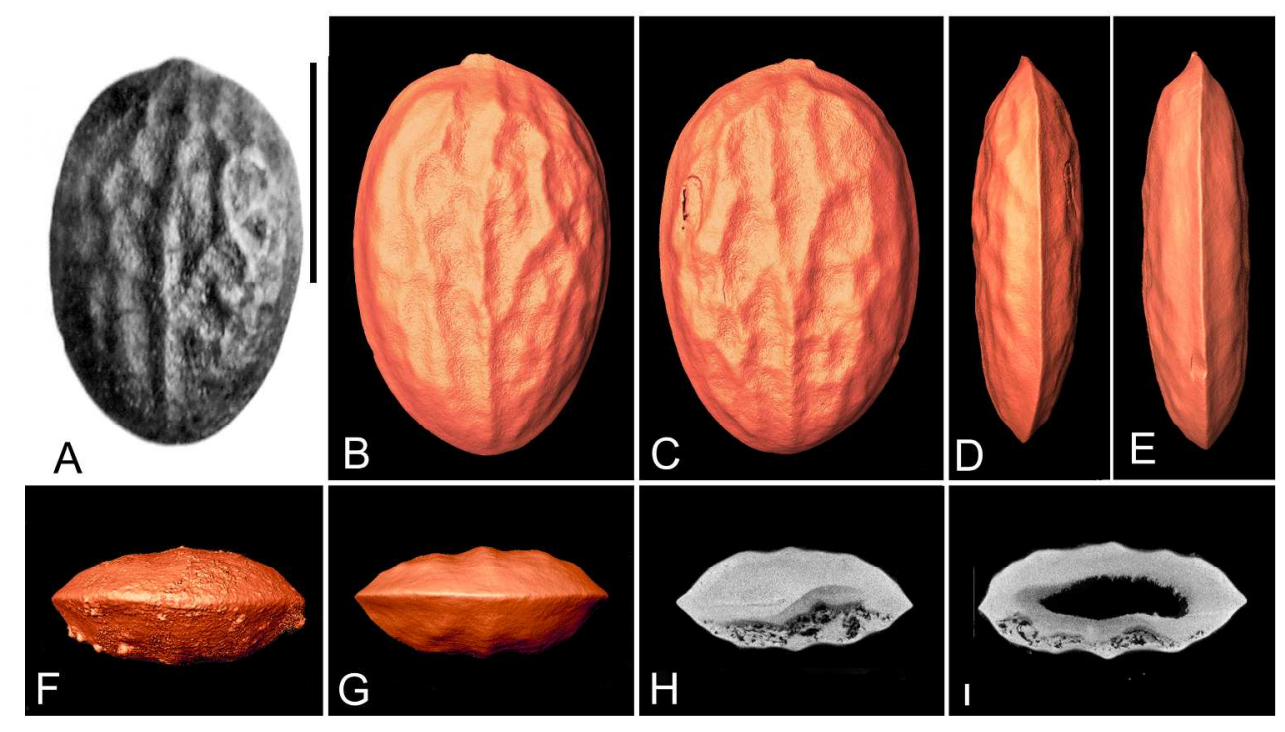

$228 \times 285 \mathrm{~mm}(300 \times 300 \mathrm{DPI})$ 

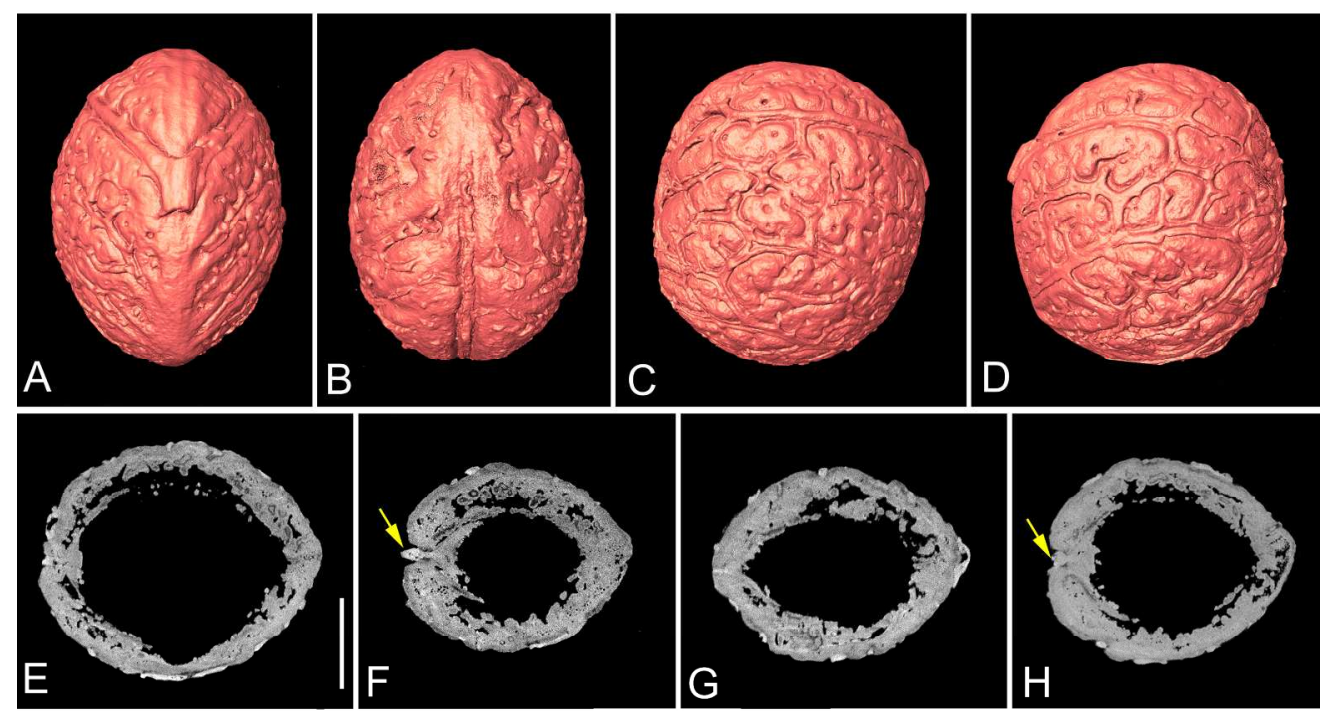

$228 \times 266 \mathrm{~mm}(300 \times 300 \mathrm{DPI})$

https://mc06.manuscriptcentral.com/botany-pubs 


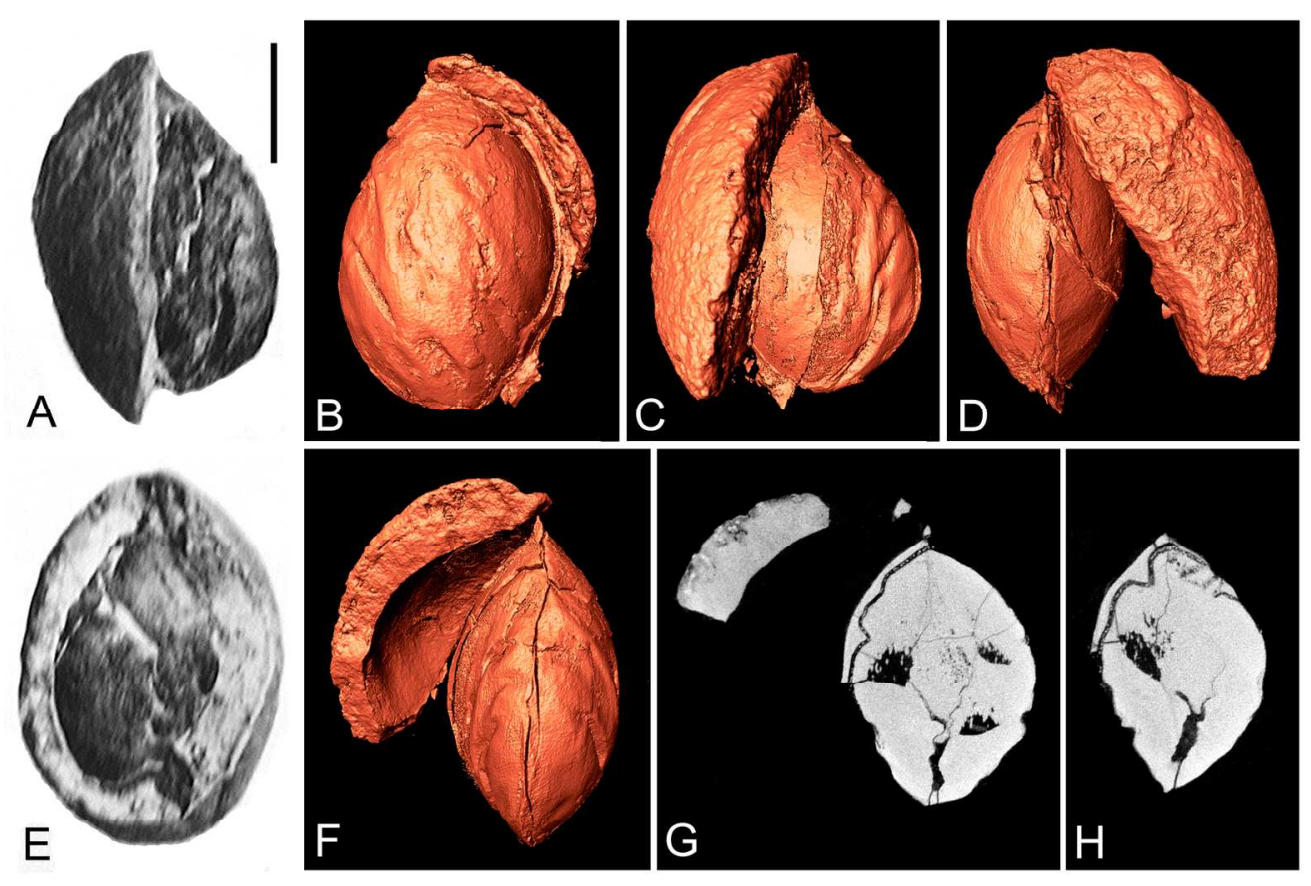

$172 \times 163 \mathrm{~mm}(300 \times 300 \mathrm{DPI})$ 


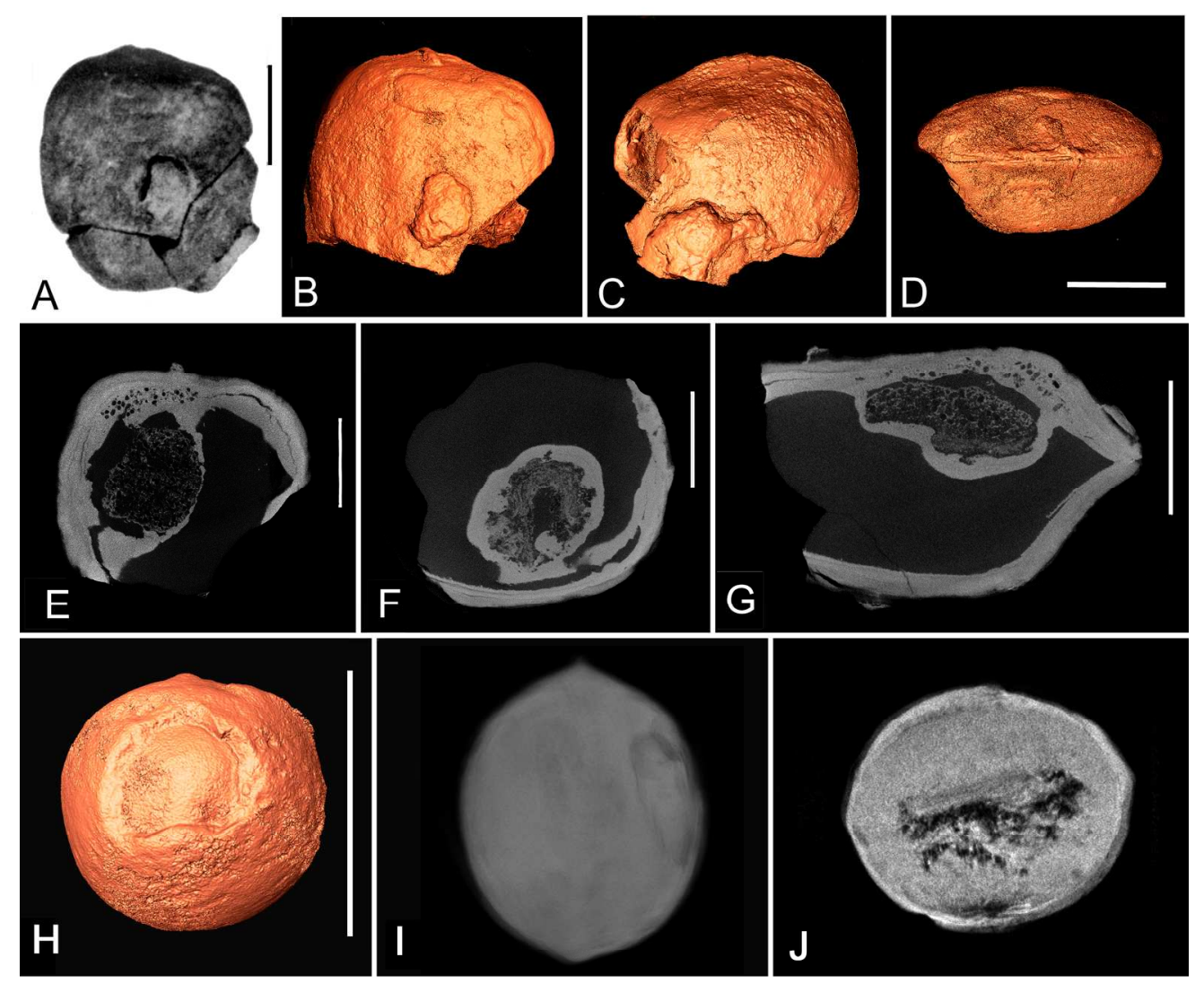

$198 \times 214 \mathrm{~mm}(300 \times 300 \mathrm{DPI})$ 
Appendix 1. Taxa from the London Clay flora not scanned for this study, including reasons for their exclusion.

Icacinicarya amygdalodea Chandler. The two specimens organic and strongly compressed, making them unsuitable for $\mu \mathrm{CT}$ scanning; not obvious that $\mu \mathrm{CT}$ would provide new data.

Icacinicarya bognorensis Reid and Chandler. This species is represented by a single specimen, so its importance in the flora overall is apparently limited; additionally, the specimen is in three pieces.

Icacinicarya elegans (Bowerbank) Reid and Chandler. No specimens currently exist. Icacinicarya emarginata Chandler. This species is only represented by locule casts; thus $\mu \mathrm{CT}$ would not provide additional information.

Icacinicarya jenkinsi Reid and Chandler. This species is represented by a single locule cast; thus $\mu \mathrm{CT}$ would not provide additional information. Paucity of specimens also suggests that this species was not an important component of the flora.

Icacinicarya minima Reid and Chandler. All available endocarps are abraded and pyritised with no organic material; other specimens are locule casts or seeds.

Icacinicarya mucronata Chandler. This species is represented by only one specimen suggesting limited importance in flora overall; the specimen is a locule cast with fragments of endocarp so unlikely to be informative.

Icacinicarya ovoidea Reid and Chandler. Only represented by locule casts.

Palaeophytocrene foveolata var. minima Reid and Chandler. Only a variety of $P$. foveolata, which was included in our $\mu \mathrm{CT}$ sampling.

Stizocarya oviformis Reid and Chandler. We examined the type species instead; this 
species is represented by only one specimen suggesting limited importance in flora overall; the specimen is a locule cast with fragments of endocarp so unlikely to be informative.

Appendix 2. Voucher information of specimens examined for fruit morphology. Herbarium codes follow the Index Herbariorum (http://sweetgum.nybg.org/science/ih/). ICACINACEAE. Alsodeiopsis staudtii Engl. - Vigne 168 (K), Ghana. Alsodeiopsis zenkeri Engl. - de Wilde 1549 (K), Cameroon. Casimirella rupestris (Duke) R. A. Howard. Nee 42943 (U), Brazil. Cassinopsis sp. - R. Capuron 27482 SF (P), Madagascar. Cassinopsis madagascariensis Baill. - P. P. Lowry 5162 (P), Madagascar. Desmostachys tenuifolius Pellegr. ex Villiers - Brenan 9276 (K), Cameroon. Desmostachys vogelii (Miers) Stapf - Leeuwenberg 2646 (MO), Ivory Coast. Hosiea japonica Makino - Okudaira 60474 (UC), Japan. Hosiea sinensis (Oliver) Hemsley \& E. H. Wilson - Sino.-Amer. Exp. 1082 (A), China. Icacina mannii Oliv. - Leeuwenberg 2708 (UC), Ivory Coast. Iodes africana Welw. ex Oliv. - Breteler et al. 8231 (MO), Gabon. Iodes klaineana Pierre - de Wilde et al. 606 (MO), Gabon. Iodes ovalis Blume - Hiep et al. HLF203 (MO), Vietnam; Lau 148 (MO), China. Iodes perrieri Sleumer Jongkind 3696 (MO), Madagascar. Iodes scandens (Becc.) Utteridge and Byng Takeuchi 9320 (MO), Papua New Guinea. Iodes seretii (DeWilde) Botique - Ekwuno et al. PFO 370 (MO), Nigeria. Iodes usambarensis Sleumer - Luke 10774 (MO), Kenya. Lavigeria macrocarpa (Oliv.) Pierre - Wieringa 5840 (WAG), Cameroon. Leretia cordata Vell. - unknown 4687 (U: 054722). Mappia multiflora Lundell - Contreras 6781 (U), Guatemala. Mappianthus sp. - (MO: 04158671), China. Merrilliodendron 
megacarpum (Hemsl.) Sleum. - White N.G.F. 10076 (L), Papua New Guinea. Miquelia caudata King - King 7621 (UC). Miquelia celebica Blume - Ramos 80631(K), Philippines. Natsiatopsis thunbergiifolia Kurz - (KUN: 0649094), China. Natsiatum herpeticum Buch.-Ham. ex Arn. - Grierson 3775 (A), Bhutan. Nothapodytes sp. - Stull 130 (FLAS), China. Phytocrene anomala Merr. - SAN 118639 (K), Sabah. Phytocrene bracteata Wall - Maxwell 82-230 (MO), Singapore. Phytocrene hirsuta Blume Beccari s.n. (K), Sulawesi. Phytocrene oblonga Wall. - Pierre 2837 (UC), unknown. Pleurisanthes flava Sandw. - Pipoly 10168 (U), Guyana. Pyrenacantha acuminata Engl. - Wieringa 5017 (WAG), Gabon. Pyrenacantha humblotii (Baill.) Sleum. Lehavana 534 (MO), Madagascar. Pyrenacantha kaurabassana Baill. - Reitsma 126 (WAG), Kenya. Pyrenacantha lobata (Pierre) Byng et Utteridge - Bokdam 3062 (WAG), Congo. Pyrenacantha macrocarpa (A. Chev. ex Hutch. et Dalziel) Byng et Utteridge - Koning 1058 (WAG), Ivory Coast. Pyrenacantha repanda (Merr.) Merr.Elmer 17359 (UC), Philippines. Rhyticaryum longifolium K.Schum. \& Lauterb. Jacobs 9671 (L), New Guinea. Rhyticaryum macrocarpum Becc. - Katik 46856 (L), Papua New Guinea. Rhyticaryum sp. - Nicholson 1551 (US), New Guinea. Sarcostigma kleinii Wight \& Arn. -Saldanha 13313 (US), India. Sarcostigma paniculata Pierre Burley 2594 (K), Indonesia. Sleumeria auriculata Utteridge, Nagam. et Teo - SAN 128458 (L), Malaysia. Stachyanthus occidentalis (Keay \& J.Miège) Boutique - Hepper 229? (K), Nigeria. Stachyanthus zenkeri Engl. - Carvalho 3626 (K), unknown. Metteniusaceae. Dendrobangia boliviana Rusby - Vargas 223 (K), Costa Rica. Emmotum nitens (Benth.) Miers. - Ferreira 9283 (FLAS), Brazil. Pittosporopsis kerrii 
Craib - Stull 132 (FLAS), China. Rhaphiostylis preussii Engl. - Tonkolili Plants 1062

(K), Sierra Leone.

ONCOTHECACEAE. Oncotheca balansae Baill. - McKee 37671 (P), New Caledonia. 